Geological Society of America

Special Paper 418

2007

\title{
Paleogene-early Miocene igneous rocks and geodynamics of the Alpine-Carpathian-Pannonian-Dinaric region: An integrated approach
}

\author{
I. Kovács \\ Lithosphere Fluid Research Laboratory, Department of Petrology and Geochemistry, \\ Eötvös University, Budapest, H-1117, Pázmány Péter sétány 1/C, Hungary, and \\ Research School of Earth Sciences, Australian National University, Building 61 Mills Road, Canberra, ACT 0200, Australia \\ L. Csontos \\ Department of Physical and Historical Geology, Eötvös University, Budapest, H-1117, Pázmány Péter sétány 1/C, Hungary \\ Cs. Szabó* \\ E. Bali ${ }^{\dagger}$ \\ Gy. Falus ${ }^{\dagger}$ \\ K. Benedek $k^{\dagger}$ \\ Z. Zajacz \\ Lithosphere Fluid Research Laboratory, Department of Petrology and Geochemistry, \\ Eötvös University, Budapest, H-1117, Pázmány Péter sétány 1/C, Hungary
}

\begin{abstract}
A review of Paleogene-early Miocene igneous rocks of the Alpine-CarpathianPannonian-Dinaric region is presented in this paper. We attempt to reveal the geodynamic link between Paleogene-early Miocene igneous rocks of the Mid-Hungarian zone and those of the Alps and Dinarides. Our summary suggests that Paleogene-early Miocene igneous rocks of all these areas were formed along a single, subduction-related magmatic arc. The study also highlights orthopyroxene-rich websterite mantle xenoliths from west Hungary and east Serbia that were formed in the vicinity of a subducted slab. We discuss the location and polarity of all potential subduction zones of the area that may account for the igneous rocks and orthopyroxene-rich mantle rocks. However, results of seismic tomography on subducted slabs beneath the studied area combined with geological data demonstrate that igneous rocks and mantle rocks cannot be explained by the same subduction process. We propose that the Paleogene-early Miocene arc was mainly generated by the Budva-Pindos subduction zone, subordinately by Penninic subduction, whereas mantle rocks were possibly formed in the vicinity of the older Vardar subduction zone. Continental blocks possibly moved together with their mantle lithosphere. The present diverging shape of the proposed arc has been achieved by considerable shear and rotations of those lithospheric blocks.
\end{abstract}

Keywords: geodynamics, Tertiary igneous rocks, mantle xenoliths, subduction, Alps, Carpathians, Dinarides, Pannonian Basin.

\footnotetext{
*Corresponding author: Szabo: cszabo@cerberus.elte.hu.

${ }^{\dagger}$ Present addresses: Bali-Bayerisches Geoinstitut, University Bayreuth, Universitätsstraß 30, D-95447 Bayreuth, Germany; Falus—Eötvös Loránd Geophysical Institute, H-1145, Columbus u. 17-23, Hungary; Benedek — Golder Associates Hungary Kft., H-1021 Budapest, Hüvösvölgyi út 54, Hungary; Zajacz-Institute of Isotope Geochemistry and Mineral Resources, Sonneggstrasse 5, ETH Zentrum, 8092 Zürich, Switzerland.

Kovács, I., Csontos, L., Szabó, Cs., Bali, E., Falus, Gy., Benedek, K., and Zajacz, Z., 2007, Paleogene-early Miocene igneous rocks and geodynamics of the Alpine-Carpathian-Pannonian-Dinaric region: An integrated approach, in Beccaluva, L., Bianchini, G., and Wilson, M., eds., Cenozoic Volcanism in the Mediterranean Area: Geological Society of America Special Paper 418, p. 93-112, doi: 10.1130/2007.2418(05). For permission to copy, contact editing@geosociety.org. (C)2007 Geological Society of America. All rights reserved.
} 


\section{INTRODUCTION}

The Carpathian-Pannonian region contains many Tertiary volcanic and plutonic centers. Most reviews of the area, however, (Szabó et al., 1992; Mason et al., 1998; Harangi, 2001; Seghedi et al., 2004) do not consider their relations with similar igneous rocks in the Dinarides (Pamić et al., 2002a; Cvetković et al., 2004a) and in the Alps (Kagami et al., 1991; von Blanckenburg et al., 1992; von Blanckenburg et al., 1998). The present paper is an attempt to discuss some of those links.

The igneous rocks of the Alps, Carpathians, Pannonian region, and Dinarides show a wide spatial, temporal, and petrographic distribution. Previous authors (i.e., Szabó et al., 1992; Pamić et al., 2002a) have pointed out that Tertiary igneous rocks fall into several groups by age (Paleogene, early Miocene, and middle Miocene-Pleistocene), but their mutual relationships have not been discussed in detail. We will focus mainly on the late Eocene to early Oligocene and late Oligocene to early Miocene groups (according to our terminology; Table 1) and their spatial relations and links to the structural evolution of the area. Efforts have been already made to link magma generation of these groups to geodynamic processes, especially to subduction (Szabó et al., 1992; Csontos, 1995; von Blanckenburg et al., 1998; Harangi, 2001; Pamić and Balen, 2001; Pamić et al., 2002b; Kázmér et al., 2003; Benedek et al., 2004; Seghedi et al., 2004). However, to date, no consistent and comprehensive model has been proposed that can explain magma generation without raising either space or time problems. This paper discusses this problem and gives one possible explanation.

In order to answer the above-mentioned problems, the Paleogene-early Miocene igneous rocks of the Alpine-CarpathianPannonian-Dinaric region are summarized and a discussion is presented about their spatial and temporal distribution (Table 1). Their geochemical features and radiometric ages, along with other similar igneous rocks in the study region, are also reported. Special attention is paid to their subduction-related signatures.

TABLE 1. LOCATION, AGE, AND PETROGRAPHY OF THE PALEOGENE-EARLY MIOCENE IGNEOUS ROCKS

\begin{tabular}{|c|c|c|c|c|}
\hline Zone $^{\dagger}$ & Locality & Age (Ma) & Petrography & References ${ }^{*}$ \\
\hline \multicolumn{5}{|c|}{ Late Oligocene-Early Miocene volcanics } \\
\hline $\mathrm{MHZ}$ & Bükk-Kács & 20 & rhyolite & [1] \\
\hline $\mathrm{MHZ}$ & Bükk-Sály & 17 & rhyolite & [1] \\
\hline $\mathrm{MHZ}$ & Bükk-Bogács & 17 & rhyolite & [1] \\
\hline $\mathrm{MHZ}$ & Bükk-Kisgyőr & 17 & rhyolite & [1] \\
\hline $\mathrm{MHZ}$ & Bükk-Demjén & 18 & rhyolite & [1] \\
\hline $\mathrm{MHZ}$ & $\begin{array}{c}\text { Covered Basin, Great } \\
\text { Hungarian Plain }\end{array}$ & $20-14.5$ & rhyolite, rhyodacite & [2] \\
\hline $\mathrm{MHZ}$ & Mecsek Mountains & $20-13$ & rhyolite, flood tuffs & [2] \\
\hline $\mathrm{MHZ}$ & Trans-Tisza Region & $19-14$ & rhyolite & [3] \\
\hline $\mathrm{MHZ}$ & Nógrád-Novohrad & $19-16$ & rhyolite tuffs & [3] \\
\hline $\mathrm{MHZ}$ & Cserhát-Mátra Mountains & $19.5-17.6$ & rhyolite tuffs & [3] \\
\hline $\mathrm{MHZ}$ & Bükk-Gemerides & $19.2-17$ & ignimbrite, tuffs & [3] \\
\hline $\mathrm{PZ}$ & $\begin{array}{c}\text { Lepoglava, Hrvatsko } \\
\text { Zagorje }\end{array}$ & 22.8 & basaltic andesite & [4] \\
\hline PZ & $\begin{array}{c}\text { Lukovcak, Hrvatsko } \\
\text { Zagorje }\end{array}$ & 19.7 & basaltic andesite & [4] \\
\hline PZ & Smrekovec & s.e. & andesite & [5] \\
\hline$P Z$ & Hurn na Suttli & s.e. & andesite & [5] \\
\hline PZ & D. Jesenje & s.e. & basalt & [5] \\
\hline PZ & Ravna Gora & s.e. & andesite & [5] \\
\hline $\mathrm{PZ}$ & Lepoglava & s.e. & andesite & [5] \\
\hline SVZ & $\begin{array}{c}\text { Camagajevci, Drava } \\
\text { Depression }\end{array}$ & 18.3 & dacite & [4] \\
\hline SVZ & $\begin{array}{c}\text { Oil wells, South Pannonian } \\
\text { Basin }\end{array}$ & $25.9-24$ & dacite, andesite, basaltic trachyandesite & [6] \\
\hline SVZ & $\begin{array}{l}\text { Borač, Southeast } \\
\text { Pannonian Basin }\end{array}$ & $22.8-22.7$ & trachyandesite and lamprophyre & [6] \\
\hline SVZ & Mutanj & 24.2 & basalt & [7], [8] \\
\hline SVZ & Šilopaj & 25.7 & basalt & [7], [8] \\
\hline SVZ & Borač & 21.3 & basaltic andesite & [7], [8] \\
\hline SVZ & Borač & 23.9 & andesite & [7], [8] \\
\hline SVZ & Ozrem & 24.9 & andesite & [7], [8] \\
\hline SVZ & Družetić & 23.9 & analcimite & [7], [8] \\
\hline SVZ & Nova Varoš & 21.5 & analcimite & [7], [8] \\
\hline SVZ & Trijebine & 23.0 & analcimite & [7], [8] \\
\hline SVZ & Devaje & 21.9 & phonolite & [7], [8] \\
\hline \multicolumn{5}{|c|}{ Late Oligocene-Early Miocene plutonic rocks } \\
\hline SVZ & Mount Golija & $20-17.5$ & granodiorite, quartz monzonite & [6] \\
\hline SVZ & Mount Željin & $24-17$ & quartz diorite, tonalite, granodiorite & [6] \\
\hline
\end{tabular}


TABLE 1. (continued)

\begin{tabular}{|c|c|c|c|c|}
\hline Zone $^{\dagger}$ & Locality & Age (Ma) & Petrography & References ${ }^{*}$ \\
\hline \multicolumn{5}{|c|}{ Late Eocene-Early Oligocene volcanics } \\
\hline $\mathrm{MHZ}$ & Zala Basin & $34.9-27.1$ & andesite, dacite, basaltic andesite & [9] \\
\hline $\mathrm{MHZ}$ & Velence Mountains & $36.8-29.1$ & andesite & [9] \\
\hline $\mathrm{MHZ}$ & Buda Mountains & $34.3-32.2$ & andesite & [9] \\
\hline $\mathrm{MHZ}$ & Recsk Mountains & 37 & andesite & [9] \\
\hline $\mathrm{MHZ}$ & Recsk Mountains & early Oligocene (s.e.) & andesite & [10] \\
\hline $\mathrm{PZ}$ & Sesia-Lanzo & $33-29$ & $\begin{array}{c}\text { basalt, basaltic andesite, andesite, trachyandesite, } \\
\text { lamprophyre }\end{array}$ & [6] \\
\hline PZ & Rhaetian Alps & $32.4-30.8$ & \multirow{2}{*}{$\begin{array}{l}\text { basalt, basaltic andesite, andesite } \\
\text { trachyandesite }\end{array}$} & [6] \\
\hline SVZ & \multirow{2}{*}{$\begin{array}{c}\text { Fruška Gora Mountains } \\
\text { Oil wells, South Pannonian } \\
\text { Basin }\end{array}$} & $36-31.6$ & & [6] \\
\hline SVZ & & 31.7 & trachyandesite & [6] \\
\hline SVZ & Srebrenica-Maglaj & $30.4-28.5$ & \multirow{4}{*}{$\begin{array}{l}\text { trachyandesite, trachydacite, andesite } \\
\text { dacite, trachyandesite } \\
\text { andesite, trachydacite } \\
\text { andesite, trachyte, dacite, ignimbrite }\end{array}$} & [6] \\
\hline SVZ & Rogozna & $33-27$ & & [6] \\
\hline SVZ & Mount Kopaonik-Ibar & $32-29$ & & [6] \\
\hline SVZ & Zletovo-Kratovo & $32-26$ & & [6] \\
\hline SVZ & Bučim-Borov Dol & $27.5-24.7$ & \multirow{3}{*}{$\begin{array}{c}\text { trachyandesite, trachydacite, trachyte, andesite } \\
\text { trachybasalt, trachyandesite, trachyte, trachydacite, } \\
\text { rhyolite }\end{array}$} & [6] \\
\hline SVZ & Kriva Palanka & 25.3 & & [6] \\
\hline SVZ & Dojran Lake & 33 & & [6] \\
\hline SVZ & Veliki & 33.5 & lamproite & [7], [8] \\
\hline SVZ & Zabrdica & 25.6 & lamproite & [7], [8] \\
\hline SVZ & Avala & 30.9 & kersantite & [7], [8] \\
\hline SVZ & Bukulja & 26.0 & minette & [7], [8] \\
\hline SVZ & Boljkovac & 29.7 & trachybasalt & [7], [8] \\
\hline SVZ & Rudnik & 30.2 & lamproite & [7], [8] \\
\hline SVZ & Rudnik & 31.9 & minette & [7], [8] \\
\hline SVZ & Ozrem & 35 & lamproite & [7], [8] \\
\hline SVZ & Mionica & 29.1 & lamproite & [7], [8] \\
\hline SVZ & Bogovina & 30.0 & lamproite & [7], [8] \\
\hline SVZ & Klinovac & 32.7 & trachybasalt & [7], [8] \\
\hline \multicolumn{5}{|c|}{ Late Eocene-Early Oligocene plutonic rocks } \\
\hline $\mathrm{MHZ}$ & Zala Basin & $34.9-27.1$ & tonalite, diorite & [9] \\
\hline $\mathrm{PZ}$ & Adamello North & $35-31$ & gabbro, cumulitic hornblendite & [11] \\
\hline $\mathrm{PZ}$ & Bergell & $32-30$ & tonalite, granodiorite, gabbro, cumulitic hornblendite & [12] \\
\hline PZ & Pohorje-Karavanke & $30-28$ & tonalite, granodiorite, diorite, gabbro & [6] \\
\hline PZ & Biella & $31-29$ & granite, monzonite, syenite & [6] \\
\hline SVZ & Mount Boranja & $33.7-29.6$ & granodiorite, quartz monzonite, tonalite & [6] \\
\hline SVZ & Mount Cer & $33-22$ & quartz monzonite, granodiorite, leucocratic granite & [6] \\
\hline SVZ & Mount Bukulja & 27 & monzonite, granodiorite, granite & [6] \\
\hline \multicolumn{5}{|c|}{ Eocene igneous rocks } \\
\hline $\mathrm{MHZ}$ & Dudar & $34.8-32.7$ & andesite, basaltic andesite pebbles & [13] \\
\hline MHZ & Dudar & 32.6-31.5 & tonalite pebbles & [13] \\
\hline PZ & Lower Inntal Tertiary & 40 & andesite pebbles & [14] \\
\hline PZ & "Südl. Volschotter" & 40.5 & dacite pebbles & [14] \\
\hline $\mathrm{PZ}$ & Adamello South & $43-38$ & tonalite, granodiorite, diorite & [6] \\
\hline SVZ & Mount Motajica & 48.7 & granodiorite, monzogranite, quartz diorite, monzodiorite & [6] \\
\hline SVZ & Mount Prosara & 48.7 & alkali feldspar granite, alkali feldspar syenite, diorite & [6] \\
\hline SVZ & $\begin{array}{l}\text { Oil wells, South Pannonian } \\
\text { Basin }\end{array}$ & 55 & monzogranite, quartz diorite & [6] \\
\hline SVZ & Tisza & 59.1 & basanite & [7], [8] \\
\hline SVZ & Osoje & 62.1 & basanite & [7], [8] \\
\hline SVZ & Sokobanja & 48.8 & basanite & [7], [8] \\
\hline SVZ & Ostrovica & 49.2 & basanite & [7], [8] \\
\hline SVZ & Krupac & 51.6 & theralite & [7], [8] \\
\hline SVZ & Okruglica & 39.5 & basanite & [7], [8] \\
\hline SVZ & Pirot & 62.0 & basanite & [7], [8] \\
\hline $\begin{array}{l}\text { Note } \\
{ }^{\dagger} \mathrm{MH} \\
{ }^{\ddagger}[1] \\
\text { al. (20 } \\
\text { Less }(\end{array}$ & $\begin{array}{l}\text {-stratigraphic evidence. } \\
\text { ddle Hungarian zone, PZ- } \\
\text { di et al. (2004); [2] Hámor } \\
\text { רd references therein; [7] } \\
\text { [11] von Blanckenburg et a }\end{array}$ & $\begin{array}{l}\text { (1987); [3] Pécskay } \\
\text { rović et al. (2004a); [8 } \\
998) ;[12] \text { von Blanck }\end{array}$ & $\begin{array}{l}\text { a-Vardar zone. } \\
\text { I. (1995); [4] Pamić et al. (1995); [5] Altherr et al. (1995 } \\
\text { vanović et al. (2001); [9] Benedek (2002) and referenc } \\
\text { urg et al. (1992); [13] Benedek et al. (2001); [14] Brüg }\end{array}$ & $\begin{array}{l}\text { ] Pamić et } \\
\text { herein; [10] } \\
\text { al. (2000). }\end{array}$ \\
\hline
\end{tabular}


Alkali basaltic rocks in the region contain mantle xenoliths (e.g., Downes et al., 1992, 1995a; Szabó et al., 1993; Nédli and M. Tóth, 1999; Embey-Isztin et al., 2001; Cvetković et al., 2004b; Szabó et al., 2004), which provide valuable information on the heterogeneous lithospheric mantle beneath the area. Newly discovered orthopyroxene-rich mantle xenoliths from western Hungary and eastern Serbia (Bali, 2004; Cvetković et al., 2004b; Bali et al., 2004, 2006) have proved that xenoliths are capable of providing valuable information on geodynamics. Furthermore, they can significantly improve our view on geodynamics when combined with traditional geological data. Until now, this information has not been used in geodynamic reconstructions of the region. Some recent geophysical data (Koulakov et al., 2002; Lippitsch et al., 2003) have also contributed to our knowledge of the lithospheric structure of the eastern Alps and Dinarides, which may in return necessitate a reevaluation of present geodynamic models of the region.

Finally, we attempt to shed light on some aspects of Tertiary structural evolution of the area, which include: (1) relation of Tertiary igneous rocks with a possible subduction; (2) relationship of structural evolution with spatial arrangement of igneous rocks; and (3) the effect of magmatism on structural evolution.

\section{GEOLOGICAL BACKGROUND}

The studied region includes several mountain chains: the eastern Alps, the Carpathian arc, and the Dinarides. These surround the Intra-Carpathian Basin system, the internal part of which is commonly referred to as the Pannonian Basin. The mountain chains all have an external belt made of externally verging turbidite nappes (flysch belts) and more internal nappes composed of crystalline to Mesozoic sedimentary rocks (Fig. 1). On top of these sequences near the periphery of the Intra-Carpathian Basin system, there is a late Tertiary calk-alkaline volcanic arc. The Intra-Carpathian Basin system has a significantly extended continental crust, which outcrops in several smaller internal mountains and is filled by middle to late Miocene sediments.

Based on the facies of Paleogene sediments, Mesozoic tectonostratigraphy, and structural analysis, the internal area is subdivided into several major units (Csontos, 1995; Haas et al., 1995, 2000; Kovács et al., 2000; Csontos and Vörös, 2004): Alcapa (Alps-Carpathians-Pannonian, i.e., northern Intra-Carpathian Basin system and Western Carpathians), Dinarides, and TiszaDacia (southern Intra-Carpathian Basin system; East and South Carpathians) (Fig. 1). The southern Alps form a natural continuation of the Dinarides, and the eastern Alps (Austroalpine units) form a natural continuation of Alcapa, whereas Tisza-Dacia forms a natural continuation of the Serbo-Macedonian mountain chains.

According to its distinct evolution during the Paleogeneearly Miocene, a further structural element is distinguishable. This is the Mid-Hungarian unit (Fig. 1), which is composed of the Bükk Mountains (N Hungary) and a narrow structural belt between Lake Balaton and the Mecsek Mountains (SW Hungary). It is composed of low- to high-pressure metamorphic Paleozoic-Mesozoic continental margin sediments, a mélange, and dispersed remains of a Jurassic ophiolite nappe (Wein, 1969; Haas et al., 2000; Csontos and Vörös, 2004). The natural continuation of this unit is found in the Internal Dinarides, and it can be directly correlated to rocks exposed near Zagreb (Fig. 1) (Wein, 1969; Csontos, 1999; Haas et al., 2000; Pamić et al., 2002b). The Mid-Hungarian unit was strongly deformed during Tertiary times (Balla, 1987; Csontos and Nagymarosy, 1998).

In this paper, the Alcapa unit is defined as the unit bounded to the south by the Periadriatic and Balaton faults (Balla, 1984; Csontos, 1995; Fodor et al., 1998, 1999) (Fig. 2). The Balaton fault separates Alcapa from the Mid-Hungarian unit. The major fault separating the Mid-Hungarian unit from the Tisza unit to the south is called the Mid-Hungarian (or Zagreb-Zemplin) fault (Wein, 1969; Balla, 1984; Csontos and Nagymarosy, 1998; Haas et al., 2000; Kovács et al., 2000) (Figs. 1 and 2).

A peculiar sedimentary unit, the buried Szolnok flysch belt (Fig. 2), is found on the northern margin of Tisza-Dacia unit (Szepesházy, 1973; Nagymarosy and Báldi-Beke, 1993). This belt predominantly consists of turbidite deposits that vary in age from Late Cretaceous to early Miocene. The rocks of this unit have a direct continuation in the Maramures flysch of the northern Eastern Carpathians. Stratigraphic equivalents of these turbidites are proposed to be found in the most internal, northern part of the Dinarides, in the Pozega, Psunj, and Motajica Mountains (Pamić et al., 1998) (Fig. 2).

The Dinarides are subdivided into a number of structural units (Dimitrijević, 1982; Pamić, 1984). The most internal Sava-Vardar belt, as defined by Pamić et al. (1998), contains earlier obducted ophiolite nappes and ophiolite mélange; a Late CretaceousPaleogene turbiditic succession; a Senonian and Paleogene igneous complex with intrusives and effusives; and finally the metamorphosed parts of the turbidite complex. Metamorphism of the turbidite sequence appears to be related to both burial and to contact metamorphism by the intrusive bodies (Fig. 1).

The obducted Jurassic ophiolite nappes and mélange lie above a weak- to high-pressure metamorphosed continental margin, most of which is composed of Mesozoic carbonate platform sediments (Pamić, 1998). Here, this unit is called the Dinaric platform. Internal Paleogene thrusts may repeat the original nappe structure. The Dinaric platform is overthrusted above the Budva (or Budva-Pindos) zone. The platform is composed of Triassic mafic rocks and Late Triassic-Cretaceous slope deposits. The exposures end near Budva, but the zone might continue beneath the Dinaric overthrust into Slovenia (Aubouin et al., 1970) (Figs. 1 and 2). Finally, the Budva and the Dinaric units have been overthrusted on top of the Adriatic platform. This Mesozoic carbonate platform is covered by an Eocene (to Oligocene) turbidite succession (Figs. 1 and 2). 


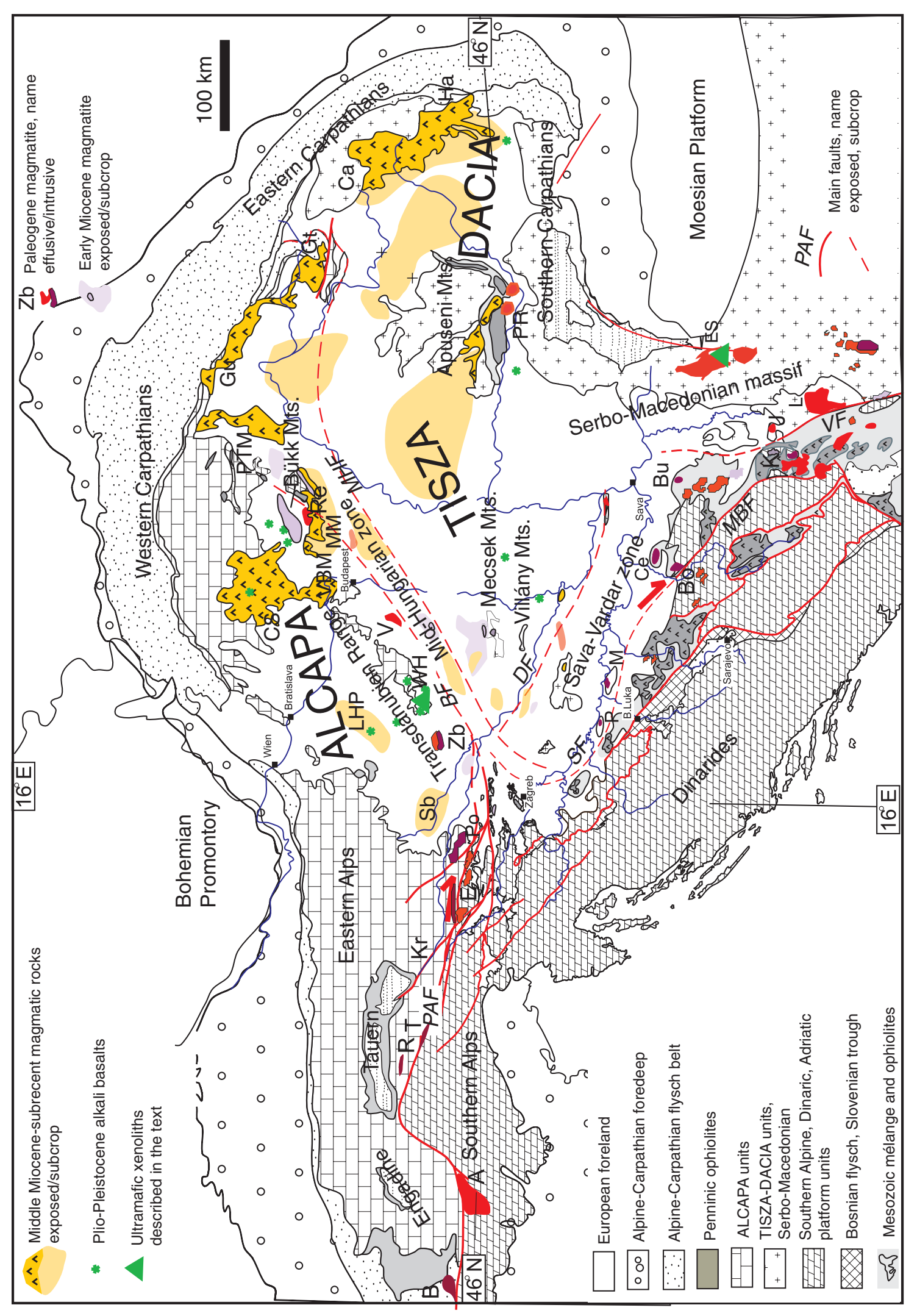

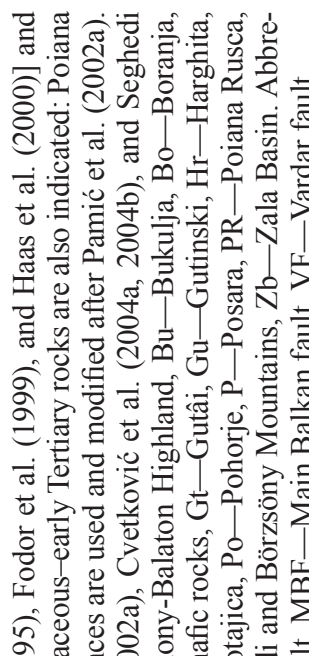
。ิ क

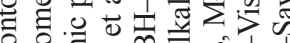

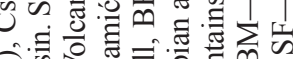

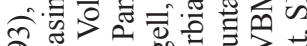

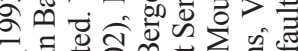

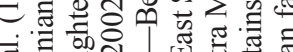
त .

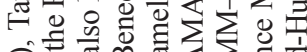

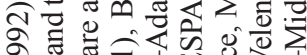
$=$ is 0 计

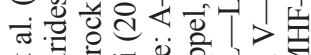
ए 해

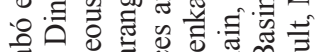

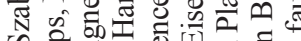

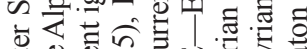

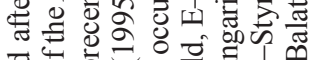

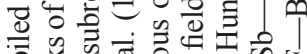
눙 政 .

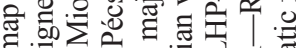
0

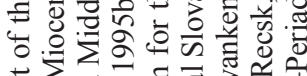

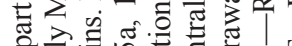

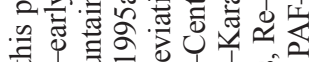

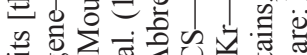

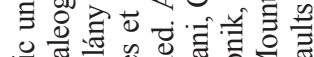

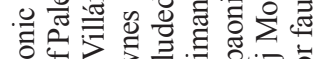
䜦

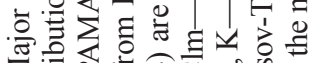

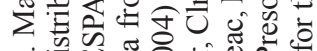

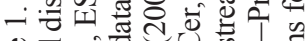

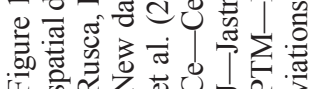




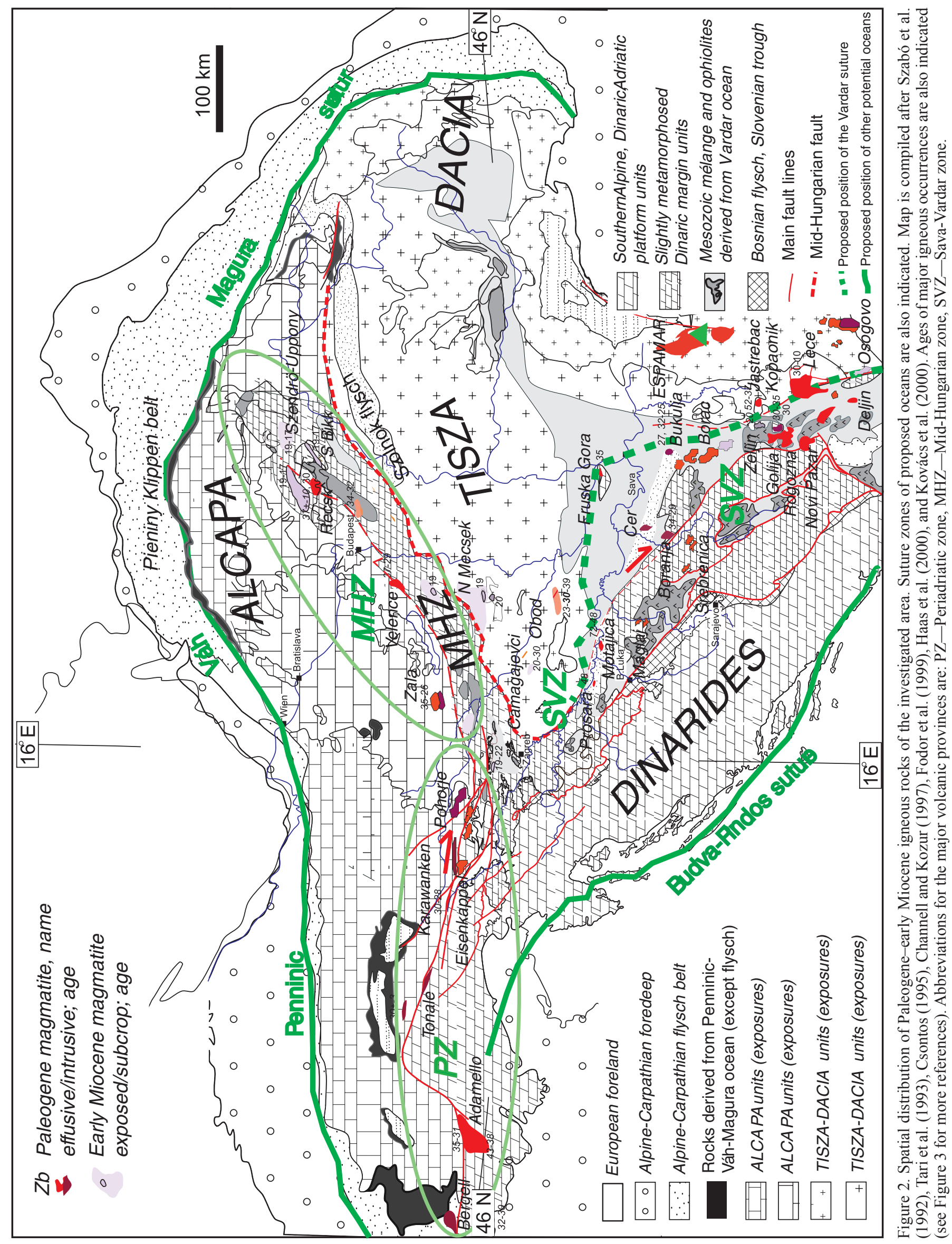




\section{TERTIARY IGNEOUS ROCKS OF THE ALPINE- CARPATHIAN-PANNONIAN-DINARIC REGION}

\section{General Distribution of Tertiary Magmatic Rocks}

The map of the Alpine-Carpathian-Pannonian-Dinaric region (Fig. 1; Table 1) indicates all magmatic rocks in outcrop and subcrop. These Tertiary igneous rocks can be classified into five suites according to their age and geochemical features, since alkaline mafic extrusions have to be distinguished from other middle Miocene-Pleistocene rocks and there are some Eocene plutonic rocks as well (e.g., Pamić et al., 2002a; Seghedi et al., 2004). Therefore, these suites include: Miocene-Pliocene (eventually Pleistocene) alkali mafic extrusions; middle Miocene to subrecent calc-alkaline volcanic rocks with their subordinate intrusives; late Oligocene-early Miocene voluminous calkalkaline volcanic rocks and tuffs with some intrusive bodies; late Eocene-early Oligocene acidic-intermediate intrusives with local volcanic successions; and finally Eocene plutonic rocks (we refer to the latter three as Paleogene-early Miocene). Alkali basalts and the middle Miocene to subrecent volcanics are limited to the Pannonian Basin and the inner margin of the Carpathian arc (Fig. 1). On the other hand, the Paleogene-early Miocene magmatic rocks occur in linear zones, three of which can be distinguished: the Periadriatic, the Mid-Hungarian, and the Sava-Vardar zones, detailed below. In the Mid-Hungarian zone, the Paleogene-early Miocene and the middle Miocene-late Miocene volcanics significantly overlap (Fig. 1).

There are also some Late Cretaceous-early Tertiary magmatic rocks (e.g., alkali basalts of Poiana Rusca [Downes et al., 1995b], east Serbian Paleogene mafic alkaline rocks [Cvetković et al., 2004a, 2004b], Late Cretaceous lamprophyres of both the Villány Mountains [Nédli and M. Tóth, 1999] and the NE Transdanubian Range [Szabó et al., 1993]); however, their detailed interpretation is beyond the scope of the present paper, since they lie beyond the linear zones defined by the Paleogene-early Miocene igneous rocks with which we are now concerned.

\section{Distribution of Paleogene-Early Miocene Magmatic Rocks}

In this section, we focus on the Paleogene-early Miocene volcanism of the study area. Distribution of Paleogene-early Miocene magmatic rocks is shown in Figure 2. Simplifying and extending the idea of Pamić et al. (2002a), Paleogene-early Miocene igneous rocks of the studied region are classified into three regional zones: (1) the Periadriatic zone; (2) the Sava-Vardar zone; and (3) the Mid-Hungarian zone (Fig. 2). The Periadriatic zone mainly consists of plutonic rocks in the vicinity of the Periadriatic fault from the Biella pluton to the Reisenferner pluton (Fig. 2). This zone also includes magmatic rocks of the Karawanken and Pohorje and extends to the Mid-Hungarian fault to the southeast.

The Sava-Vardar zone stretches from this junction (from the Prosara and Motajica Mountains) to the igneous rocks of
Osogovo-Lisets. Other igneous bodies found farther south (Dorian, Sithonia, Kavala) are clearly the continuation of the previous magmatites, although these are not reported here in detail. The western border of the Sava-Vardar zone is hard to define, although it likely appears at the northern edge of the Dinaric platform. This magmatic zone seems to be parallel to the Main Balkan fault and the Vardar fault (Fig. 2). Nevertheless, east Serbian Paleogene alkaline mafic rocks (Cvetković et al., 2004a, 2004b) are somewhat older and do not match perfectly with the Paleogene-early Miocene igneous zone, since these are $100 \mathrm{~km}$ to the east from its main strike (Fig. 2). Thus, we distinguish them in this paper from the Paleogene-early Miocene zone.

A third group is formed by the Mid-Hungarian zone magmatic rocks. This group stretches from the Zala Basin in the south to the Bükk Mountains in the north (Fig. 2). Voluminous Paleogene-early Miocene and younger volcanics are buried under the Neogene sediments of the Pannonian Basin, the exact characters of which have not yet been established, although some scarce data are available from boreholes (Dunkl and Nagymarosy, 1990; Pécskay et al., 1995; Benedek, 2002; Seghedi et al., 2004) (Fig. 2). This magmatic zone finds its continuation both in the Sava-Vardar zone and Periadriatic zone at its southwest junction near Zagreb. The NE-SW strike of the Mid-Hungarian zone is almost perpendicular to those of the Sava-Vardar zone and Periadriatic zone and is parallel to the Balaton and Mid-Hungarian faults. All aforementioned igneous rocks align parallel to major tectonic lines, and they form a relatively narrow zone (150 $200 \mathrm{~km}$ ) along these faults (Figs. 1 and 2).

The temporal classification of these igneous rocks is based on their radiometric age and geochemical features (Pamić et al., 2002a). These define three main episodes in Paleogene-early Miocene igneous activity: an Eocene event (60-37 Ma), which is subordinate both in terms of its volume and spatial extent, a late Eocene-early Oligocene event (36-25 Ma), and a late Oligocene-early Miocene (25-17.5 Ma) event. Pamić et al. (2002a) originally used the terms "Eocene," "early Oligocene," and "Egerian-Eggenburgian, for these respective age groups. We refer to them here otherwise, in order to avoid using local stratigraphic terms. From the cumulated radiometric data, it appears that all three magmatic zones (Periadriatic zone, Sava-Vardar zone, Mid-Hungarian zone) show near-continuous igneous activity from the Eocene until the end of the early Miocene, or in the case of the Mid-Hungarian zone, until the middle Miocene. Three peak activity periods, however, appear in each zone at $45 \mathrm{Ma}, 30 \mathrm{Ma}$, and $20 \mathrm{Ma}$ (Fig. 3).

The Eocene group includes granitoids in the Periadriatic zone (Adamello ca. $40 \mathrm{Ma}$ ) and Sava-Vardar zone (i.e., Motajica, Prosara, ca. $48.7 \mathrm{Ma}$ ), which preceded the main phase of Paleogene-early Miocene igneous activity (Pamić et al., 2002a). Similar ages are reported for mafic alkaline rocks of east Serbia (Cvetković et al., 2004a, 2004b). Furthermore, dacite pebbles from conglomerates in the eastern Alpine molasses also display ages (ca. $40 \mathrm{Ma}$ ) corresponding to this oldest magmatic episode 


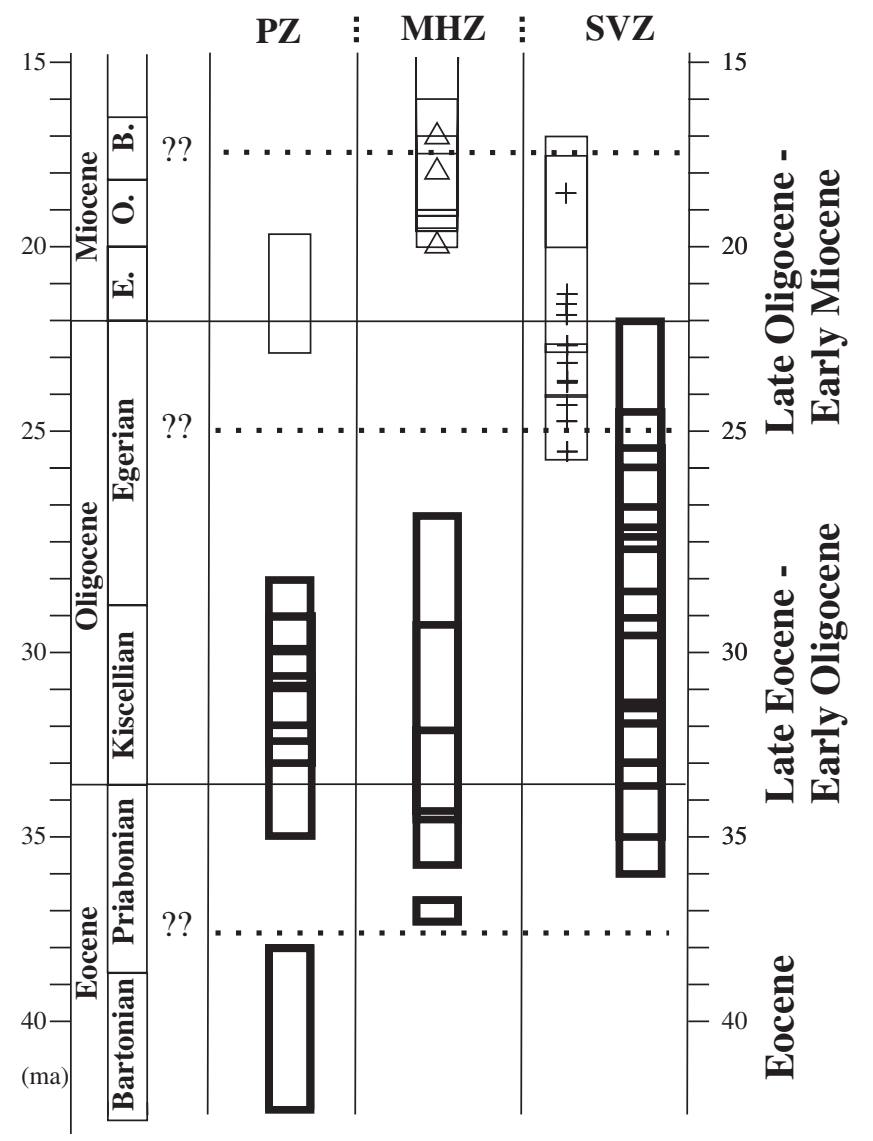

$\triangle$ Mid-Hungarian Zone (MHZ)

+ Sava-Vardar zone (VS)

$\square$ Data range for Late Oligocene - Early Miocene igneous rocks

Data range for Late Eocene - Early Oligocene igneous rocks

Figure 3. Distribution of Paleogene-early Miocene igneous activity in time and space in the Alpine-Pannonian-Dinaric region. Data are taken from Pamić et al. (1995), Pécskay et al. (1995), Less (2000), Benedek (2002), Pamić et al. (2002a), Cvetković et al. (2004a), and Seghedi et al. (2004). PZ-Periadriatic zone, SVZ-Sava-Vardar zone, MHZ-Mid-Hungarian zone, E.-Eggenburgian, O.-Ottnangian, B.-Badenian.

(Brügel et al., 2000). Andesite pebbles with similar ages have also been found in the Transdanubian Range (Benedek et al., 2001) (Fig. 1).

The main phase of Paleogene-early Miocene magmatism occurred in two episodes: in late Eocene-early Oligocene and in late Oligocene-early Miocene (Figs. 2 and 3). The earlier volcanic episode started ca. $36 \mathrm{Ma}$. This late Eocene-early Oligocene igneous episode terminated almost synchronously (ca. $28 \mathrm{Ma}$ ) in the Periadriatic zone and Mid-Hungarian zone, but continued in the Sava-Vardar zone. Hence, the boundary between the late Eocene-early Oligocene and late Oligocene-early Miocene magmatic activity cannot be clearly established in these regions simply based on radiometric ages, and igneous activity in the
Sava-Vardar zone was almost continuous from the late Eocene until the early Miocene.

While the timing of igneous activity cannot clearly fingerprint changes in igneous events, the style of igneous activity did change with time. Therefore, it is still possible to separate different magmatic episodes, even if they overlap in time. This idea was also proposed by Pamić et al. (2002a), who distinguished "early Oligocene" shoshonites and high-K volcanics from "Egerian-Eggenburgian" calc-alkaline volcanics and granitoids in the Sava-Vardar zone. These geochemical variations may reflect changing geodynamic conditions that could also have a bearing on the degree of partial melting, source region, magma transport, differentiation and contamination. This change in chemistry is also reflected in the Mid-Hungarian zone, where we can discern late Eocene-early Oligocene moderately evolved, intermediate igneous rocks (dacites and andesites) from late Oligocene-early Miocene highly evolved acidic rocks (mainly rhyolites) (Benedek, 2002).

Stratigraphic data on interfingering volcanic and sedimentary strata also suggest the same age span for at least two zones. In the Mid-Hungarian zone, early Oligocene fauna-bearing beds immediately cover lava flows in the Recsk area (Less, 1999, 2000). In wells near Budapest, a thick tuff intercalation is found in early Oligocene clays (Szabó and Szabó-Balog, 1986; Dunkl and Nagymarosy, 1990, 1992; Lakatos et al., 1992). In the Zala Basin, late Eocene sediments partly interfinger and partly underlie voluminous volcanic successions (Benedek, 2003). In the northern part of Mecsek Mountains, early Miocene layers occur below and above an andesite body (Hámor et al., 1987). Thick acidic volcanic tuff is present throughout the early Miocene continental succession of the same mountain (Máthé et al., 1997). Thick volcanites in the immediate northern vicinity are interlayered with contemporaneous and middle Miocene sediments (Figs. 1 and 2).

In the western part of the Sava-Vardar zone, Pamić (1998) identified several volcanic rocks within early Miocene sediments. In the southern part of the same zone, near the Kopaonik Mountains, voluminous andesites flow over Oligocene sediments (Figs. 1 and 2). Furthermore, thick acidic tuffs occur within early Miocene deposits (Dimitrijević, 1997).

\section{Petrology and Geochemistry of the Paleogene-Early Miocene Igneous Rocks}

Igneous rocks in the studied area are both plutonic and volcanic, with a wide variety of lithologies irrespective of locality. Plutons of Eocene (Motajica and Prosara), late Eocene-early Oligocene (e.g., Adamello, Bergell, Biella, Pohorje, Karawanken, Boranja, Cer, Bukulja, Kopaonik, Zala Basin) and late Oligocene-early Miocene (Cer, Bukulja, Golija, Zeljin) age are high-K, felsic granitoids (granodiorite, monzonite, monzodiorite, diorite, tonalite, syenite) (Kagami et al., 1991; von Blanckenburg et al., 1998; Pamić et al., 2002a; Benedek et al., 2004) (Fig. 2; Table 1). 
Volcanic rocks may be more widespread and voluminous than their plutonic counterparts, even if we consider that these rocks are buried under thick sedimentary cover and sometimes are only known from boreholes. Volcanic rocks from the Periadriatic zone are scarce and not yet well documented. Late Eocene-early Oligocene volcanics are shoshonites, high-K volcanics, and ultrapotassic rocks in the Sava-Vardar zone (Pamić et al., 2002a; Cvetković et al., 2004a). Igneous rocks in the Mid-Hungarian zone are andesites, dacites, and rarely basaltic andesites with less strongly alkaline character (Fig. 2) (Downes et al., 1995b; Benedek, 2002). Late Oligocene-early Miocene volcanics vary from high- to low-K calc-alkaline rocks (basalt, basaltic andesite, andesite, dacite, rhyodacite, rhyolite) (Altherr et al., 1995; Pécskay et al., 1995; Pamić et al., 2002a; Cvetković et al., 2004a; Seghedi et al., 2004). Nevertheless, some ultrapotassic rocks also occur in east Serbia (Cvetković et al., 2004a; Prelević et al., 2005).

Trace-element characteristics of Paleogene-early Miocene igneous rocks are quite similar; therefore, we report them uniformly, although particular features will be highlighted in each case. An entire and thorough comparison, however, is not yet possible due to the large variation in quality and quantity of the available data. These incomplete data sets are the cause for the somewhat unusual trace-element diagrams (Figs. 4A and 4B). Primitive mantle-normalized trace-element patterns (Fig. 4A) are very similar in all the three igneous zones. Strong positive large ion lithophile element (LILE), $\mathrm{Th}$, and $\mathrm{Pb}$ anomalies, and strong negative $\mathrm{P}, \mathrm{Nb}$, and $\mathrm{Ti}$ anomalies are characteristic for all igneous rocks. Plutonic rocks of the eastern Periadriatic zone display a significant negative $\mathrm{Sr}$ anomaly, whereas those rocks from the western Periadriatic zone show a similar feature of $\mathrm{Nb}$. There are no distinct differences between plutonic and volcanic rocks, irrespective of their locality, although the incompatible elements are slightly more enriched in volcanic rocks. Chondrite-normalized rare earth element (REE) patterns (Fig. 4B) show uniform features regardless of age, style, and locality. The light (L) REEs are $\sim 10$ times enriched over heavy $(\mathrm{H})$ REEs, which display a concave upward pattern. A slight negative Eu anomaly is characteristic. Sr-Nd isotopic characters also seem to be uniform, i.e., fields for the different magmatic episodes largely overlap (Fig. 5). Most rocks are in the oceanic-island arc (OIA) field, and very few samples resemble oceanic-island basalt (OIB) (Pamić et al., 2002a; Cvetković et al., 2004a; Seghedi et al., 2004).

\section{SUBDUCTION-RELATED ORIGIN OF PALEOGENE-EARLY MIOCENE MAGMATISM OF THE STUDY AREA}

\section{Former Models}

Paleogene-early Miocene rocks of the studied region show uniform geochemical characteristics in spite of their significant petrographic variety and considerable spatial and temporal spread. Their geochemical features are indicative of a com- mon subduction-related origin (Ellam and Hawkesworth, 1988) (Figs. 4 and 5). Moreover, igneous activity, especially the late Eocene-early Oligocene stage, was almost synchronous in all three magmatic zones and shows a surprisingly similar time distribution. The Paleogene-early Miocene rocks occur along major fault zones (i.e., Periadriatic fault $[\mathrm{PAF}]$, Balaton fault $[\mathrm{BF}]$, Mid-Hungarian fault [MHF], Sava fault [SF], Main Balkan fault $[\mathrm{MBF}][$ Fig. 1]) and are restricted in a relatively narrow zone along these faults.

Several geodynamic models have been proposed (Laubscher, 1983; Kagami et al., 1991; Dal Piaz and Gosso, 1993; von Blanckenburg et al., 1998) to explain the genesis of the Periadriatic zone intrusive formations, and the "slab-break off" hypothesis of von Blanckenburg et al. (1998) appears to be the most plausible. This model describes magma formation as a result of asthenosphere "intrusion" replacing the broken and sinking remnants of the oceanic slab, which triggers melting in the previously metasomatized, but not yet melted, upper mantle wedge. The Paleogeneearly Miocene igneous formations of the Sava-Vardar zone can also be related geochemically to those of the Periadriatic area. The Sava-Vardar zone igneous rocks were formed from tholeiitic melts that went through different degrees of differentiation and fractionation. Tholeiitic melts at this locality are considered to have been produced by partial melting of a previously metasomatized mantle wedge (Pamić and Balen, 2001; Pamić et al., 2002a).

Pamić and Balen (2001) proposed the existence of a single "Periadriatic-Sava-Vardar suture zone" along which Paleogeneearly Miocene rocks were generated. Subsequently, Benedek (2002) and Benedek et al. (2004) published comprehensive studies of Paleogene igneous rocks from the Zala Basin in the Pannonian Basin. These authors pointed out strong geochemical similarities of Paleogene magmatic formations from the Periadriatic zone and Mid-Hungarian zone. Intermediate volcanic and intrusive rocks from the Recsk area, as well as the Velence Mountains, have also been linked to subduction processes (Downes et al., 1995b). Their geochemical characteristics also resemble those of the Periadriatic zone and Sava-Vardar zone (Benedek, 2002; Benedek et al., 2004).

All in all, it seems highly probable that all of the Paleogeneearly Miocene magmatites were generated by either subduction or by a process closely linked to subduction. This hypothesis is further supported by two other independent sources of information: xenoliths and seismic tomography.

\section{Xenoliths: A Key to the Deep Lithosphere}

Our knowledge of the lithospheric mantle beneath the studied region has been greatly improved through petrographic, petrologic, geochemical, and isotopic studies of upper-mantle xenoliths. The xenoliths reflect the geochemical signatures and physical state of the mantle that they were sampled from. Geobarometric studies indicate their original depth, whereas geochemical studies reveal the degree of depletion or enrichment of the mantle. This study, therefore, provides evidence for possible 


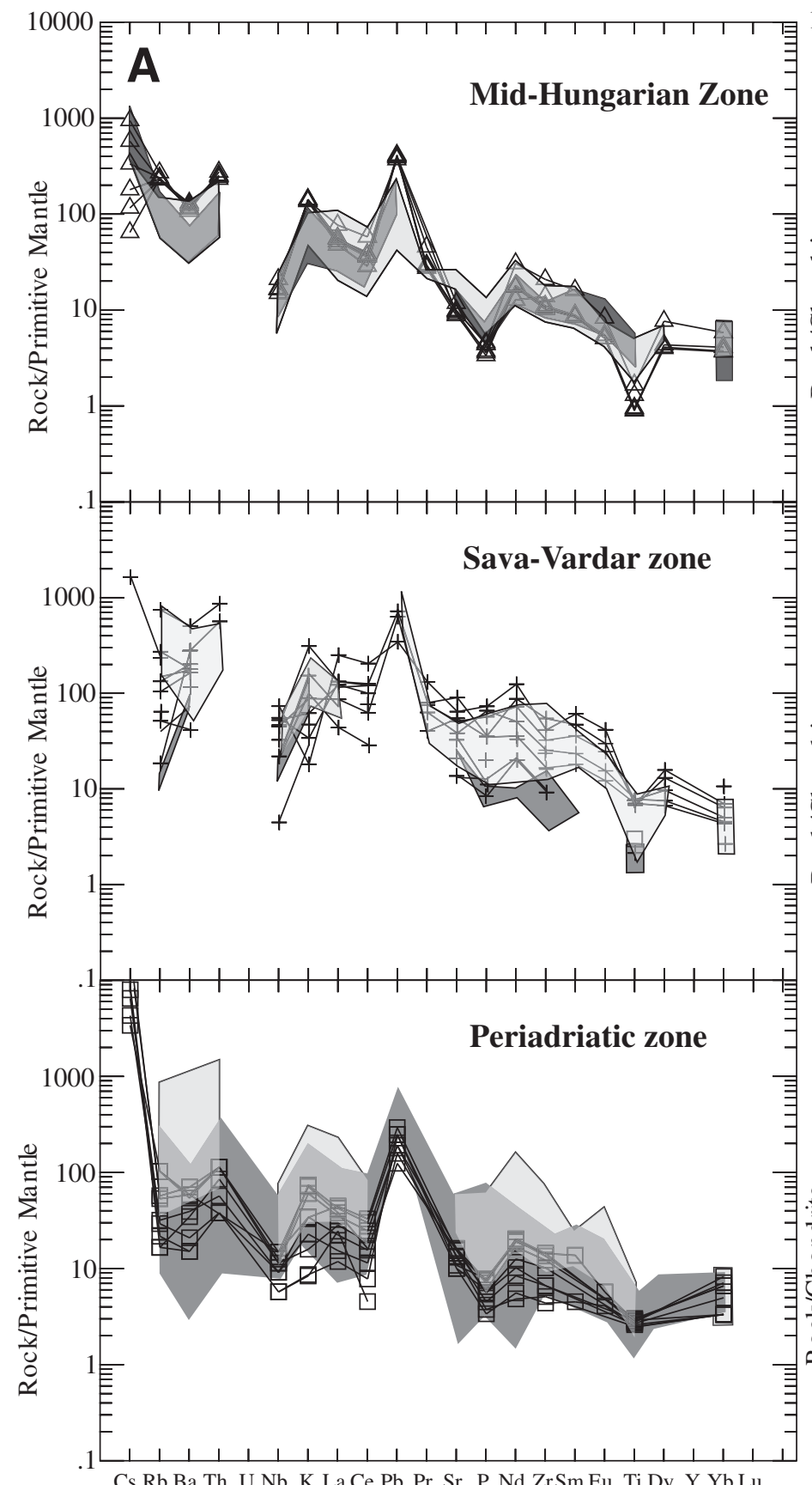

Cs Rb Ba Th U Nb K La Ce Pb Pr Sr P Nd ZrSm Eu Ti Dy Y Yb Lu

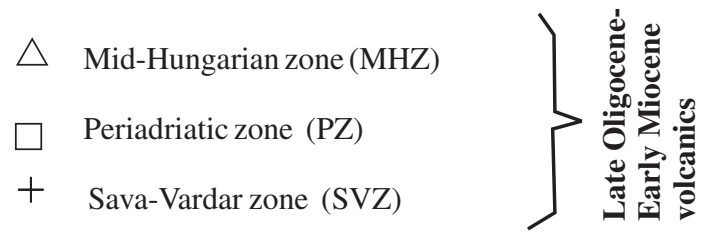

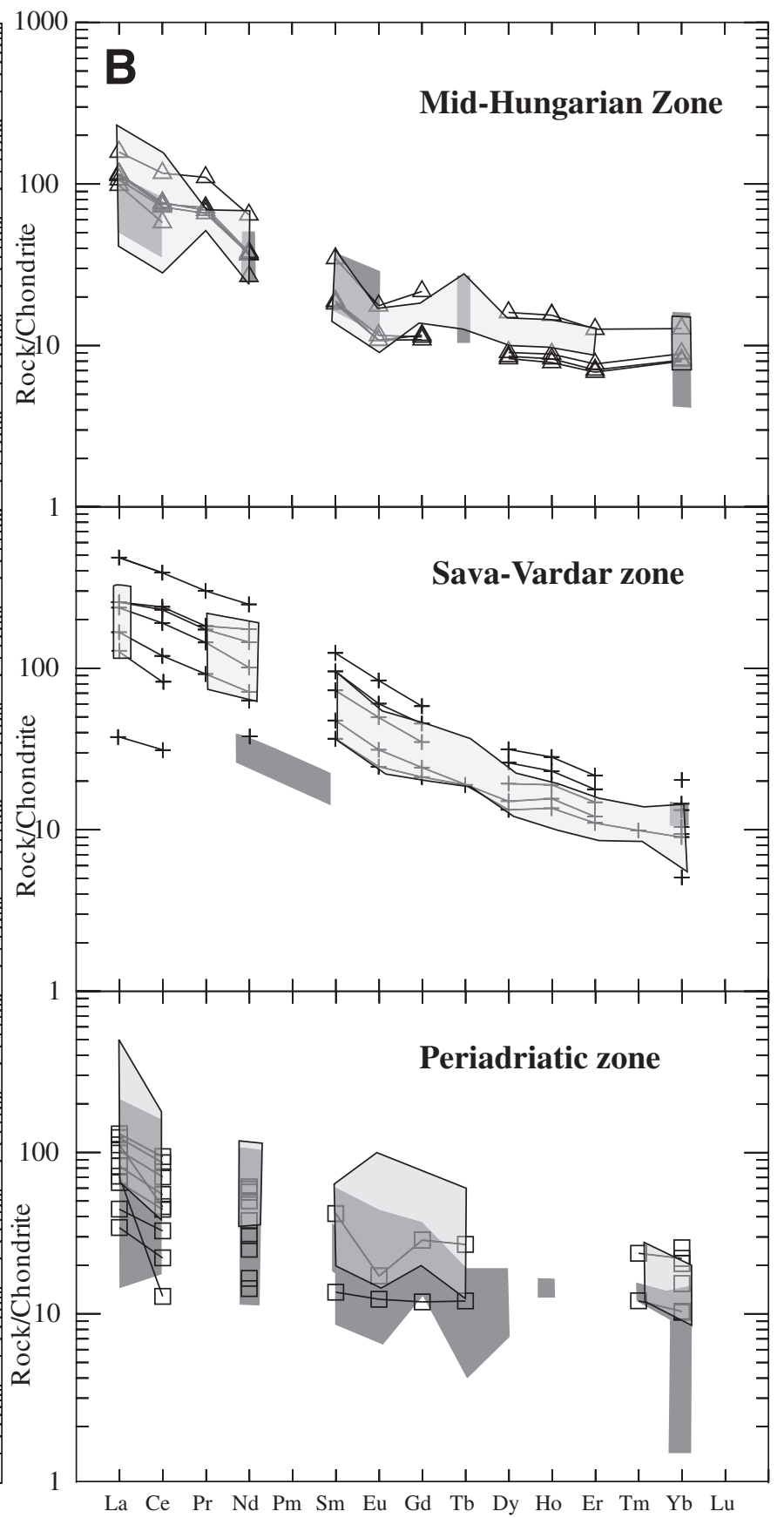

Late Eocene - Early Oligocene volcanics

Late Eocene - Early Oligocene plutons

Figure 4. (A) Primitive mantle-normalized trace-element patterns (McDonough and Sun, 1988) of Paleogene and early Miocene igneous rocks from the Alpine-Pannonian-Dinaric region. Data for the late Oligocene-early Miocene magmatites are taken from Pamić et al. (1995); Pamić et al. (2002a); Cvetković et al. (2004a); and Seghedi et al. (2004), while those for the late Eocene-early Oligocene volcanics are from Downes et al. (1995b); Pamić et al. (2002a); Benedek (2003); and Cvetković et al. (2004a). (B) Chondrite-normalized rare earth element (REE) patterns (Nakamura, 1974) of Paleogene and early Miocene volcanics from the Alpine-Pannonian-Dinaric region. Data for the late Oligocene-early Miocene volcanics are taken from Pamić et al. (1995); Pamić et al. (2002a); Cvetković et al. (2004a); and Seghedi et al. (2004), whereas those for the late Eocene-early Oligocene magmatic rocks are from Downes et al. (1995b); Pamić et al. (2002a); Benedek (2003); and Cvetković et al. (2004a). 


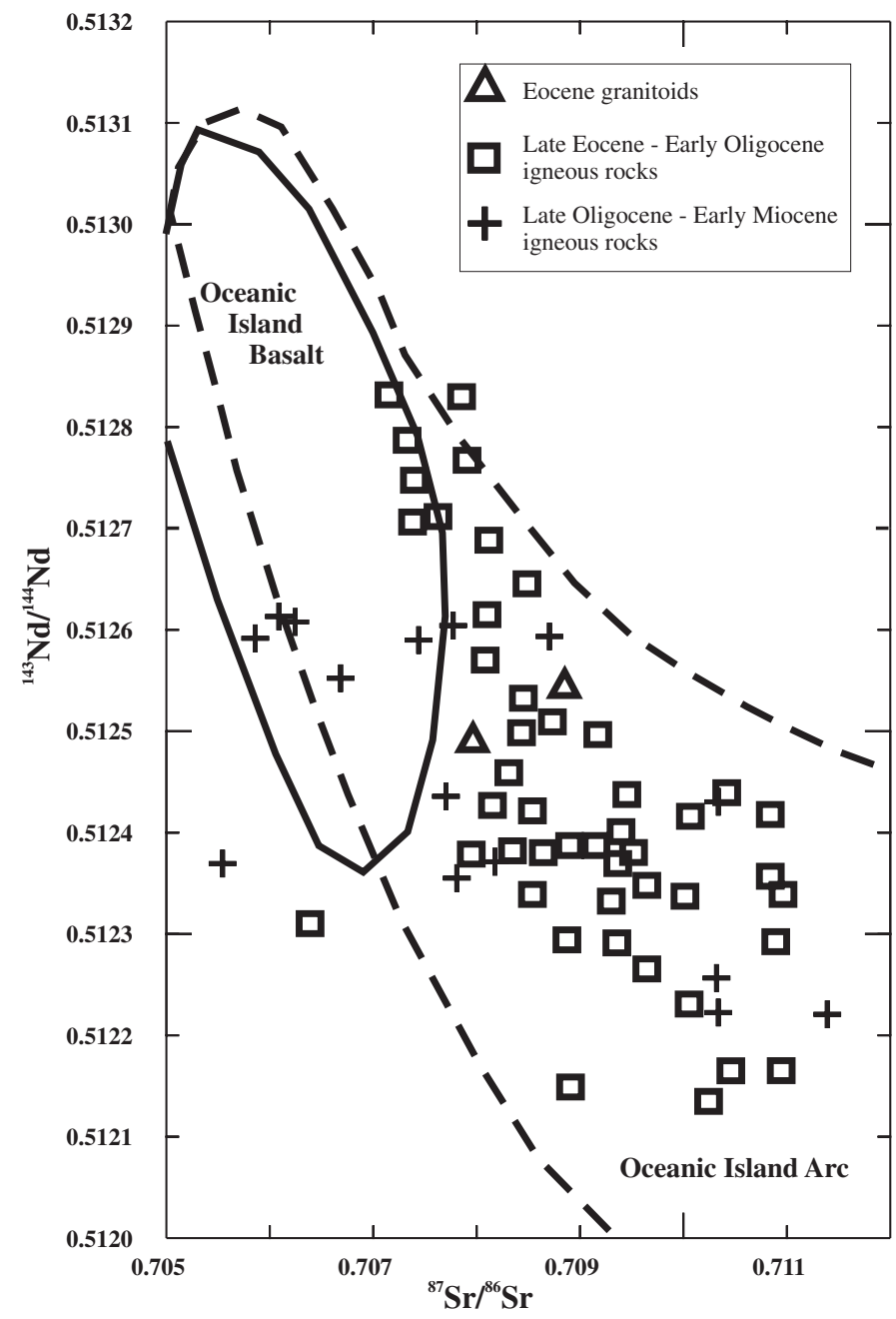

Figure 5. Plot of ${ }^{87} \mathrm{Sr} /{ }^{86} \mathrm{Sr}$ versus ${ }^{143} \mathrm{Nd} /{ }^{144} \mathrm{Nd}$. Data are taken from Pamić et al. (2002a); Cvetković et al. (2004a); and Seghedi et al. (2004). OIB - oceanic-island basalt.

subduction-related processes and, in special cases, evidence for the locus of the supposed subduction.

Most xenoliths from the Pannonian Basin are hosted in Pliocene to Pleistocene alkali basalts (Szabó et al., 2004, and references therein). These host basalts occur at the edge of the IntraCarpathian Basin system (Styrian Basin, Nógrád-Gömör, and eastern Transylvanian Basin) and in its central part (Little Hungarian Plain, Bakony-Balaton Highland) (Fig. 1). There are also some older basaltic rocks (i.e., from Poiana Rusca, east Serbia, Villány Mountains, and NE Transdanubian Range) that contain mantle xenoliths, which bear information on the state of the prePaleogene lithosphere (Szabó et al., 1993; Downes et al., 1995a; Nédli and M. Tóth, 1999; Cvetković et al., 2004b).

The upper-mantle xenoliths are mostly spinel peridotites (Downes et al., 1992; Embey-Isztin et al., 2001; Szabó et al., 2004), accompanied by subordinate pyroxenites and lowercrustal granulites in the Pannonian Basin (Dobosi et al., 2003a, 2003b; Embey-Isztin et al., 2003; Kovács et al., 2004; Kovács and Szabó, 2005). The peridotites represent residual mantle material and provide textural and geochemical evidence for a complex history of melting and recrystallization, irrespective of location within the region (Falus, 2004; Szabó et al., 2004). The lithospheric mantle sampled as xenoliths is more deformed in the center of the Intra-Carpathian Basin system than toward the edges. The deformation has been attributed to a combination of extension and upwelling of asthenosphere in the middle Miocene (Szabó et al., 2004, and references therein).

The mantle xenoliths contain hydrous phases (pargasitic and kaersutitic amphiboles, and rarely phlogopite) as evidence for modal metasomatism in all occurrences of the region. Orthopyroxene-rich lithologies, however, are rare among mantle samples (e.g., McInnes et al., 2001; Melcher et al., 2002; Santos et al., 2002). These were found only in the Pliocene-Pleistocene alkali basalts of western Hungary and in the east Serbian Paleogene mafic alkaline rocks (Fig. 1). They include orthopyroxenerich olivine websterites and a quartz-bearing orthopyroxene-rich websterite (Bali, 2004; Cvetković et al., 2004b; Bali et al., 2004, 2006). The western Hungarian xenolith location is in the vicinity of the Paleogene-early Miocene igneous rocks along the MidHungarian zone, whereas the east Serbian Paleogene rocks, in turn, are $100 \mathrm{~km}$ away to the east from the arc with which we are now concerned (Figs. 1 and 2).

Poikilitic texture in mantle xenoliths has been interpreted as being an original igneous feature (Embey-Isztin et al., 2001). The western Hungarian olivine websterites that show poikilitic texture contain orthopyroxenes with relatively low $\mathrm{Al}_{2} \mathrm{O}_{3}$ contents (up to $2.5 \mathrm{wt} \%$ ), high $\mathrm{Mg} \#$ (up to 92.3) and Cr-rich spinels (up to $43.9 \mathrm{wt} \% \mathrm{Cr}_{2} \mathrm{O}_{3}$ ), compared to those from mantle peridotites. Furthermore, these clinopyroxenes display a U-shaped REE pattern and high ${ }^{87} \mathrm{Sr} /{ }^{86} \mathrm{Sr}$ ratios $(0.70569-0.70591)$ (Bali et al., 2006). Based on textural and geochemical considerations, the orthopyroxene-rich rocks appear to be the products of interaction between boninitic melts and mantle peridotites. Similar conclusions were drawn for the genesis of orthopyroxene-rich bands in other ultramafic bodies by Melcher et al. (2002) and Santos et al. (2002).

Some orthopyroxene-rich olivine websterites from the east Serbian basanites also display many similarities (Cvetković et al., 2004b). These xenoliths show an igneous-like texture with predominant orthopyroxene that often forms tabular crystals. Olivine is idiomorphic, whereas clinopyroxene is very small. Their geochemical character resembles olivine websterite xenoliths from western Hungary, with low $\mathrm{Al}_{2} \mathrm{O}_{3}$ content in orthopyroxene $(<2 \mathrm{wt} \%)$ and very high Cr\# of the spinel (75-96). Spinels show a strong affinity to oxides formed by crystallization of mafic and ultramafic magmas rather than those found in mantle peridotites. Such extraordinary $\mathrm{Cr}$-rich spinels are found mainly in boninites and other arc-related magmas (Barnes and Roeder, 2001; Cvetković et al., 2004b).

The unique quartz-bearing orthopyroxene-rich websterite xenolith from western Hungary also shows an igneous texture 
(Bali et al., 2004), with Fe-rich orthopyroxene (Mg\# $\leq 81.8)$. Primary silicate melt inclusions in orthopyroxenes are strongly silicic, and they display steep REE patterns, strong negative $\mathrm{Nb}$, $\mathrm{Ta}$, and $\mathrm{Sr}$ anomalies, and strong positive $\mathrm{Ni}$ and $\mathrm{Cr}$ anomalies (not shown), all of which are characteristic of slab melts (Ellam and Hawkesworth, 1988; Rapp et al., 1999). This suggests that this websterite is an interaction product of a slab-derived $\mathrm{SiO}_{2}-$ saturated melt and peridotitic wall rock (Bali et al., 2004).

From petrographic and geochemical evidence, the orthopyroxene-rich mantle rocks are probably the products of interaction between boninites or subduction-related melts and mantle lithologies. The original (i.e., slab-derived) melts are highly reactive in the mantle. Therefore, it is thought that the websterites were produced in a forearc or arc setting, because melts formed in this environment cannot migrate far from their source without being completely consumed (Rapp et al., 1999). There is no direct time constraint on the formation of orthopyroxene-rich rocks, although they should be pre-Paleogene (east Serbia) and pre-Pliocene (west Hungary). The geochemical characteristics of these rocks and the fact that either they are hosted in Paleogene mafic rocks (east Serbia) or their hosts are in the vicinity of the Paleogene igneous rocks (Mid-Hungarian zone) indicate that they may have had a similar origin to the Paleogene-early Miocene igneous suite. Geochemical features of these orthopyroxene-rich xenoliths also imply that the mantle lithosphere from which they originated might have been in close proximity to a forearc and descending slab at the time of their formation. Downes et al. (1992) and Rosenbaum et al. (1997) have already proposed subduction-related characteristics of the western Hungarian mantle xenoliths based on their radiogenic isotope signatures. Furthermore, based on granulite xenoliths, Dobosi et al. (2003b) and Embey-Isztin et al. (2003) attributed a subduction-related origin to the lower crust beneath western Hungary that may also be related to the Paleogene processes.

These features are all indicative of subduction-related rocks in the uppermost mantle (and possibly lower crust). However, this raises many questions, if we assume that these rocks are contemporaneous and share a common origin with the Paleogeneearly Miocene magmas, since the northernmost subduction zone along the External Carpathians is too distant $(200-250 \mathrm{~km})$ to have produced them (Figs. 1 and 2).

\section{Seismic Tomography}

In their seismic tomographic work, Wortel and Spakman (2000) and Koulakov et al. (2002) reported remnants of an oceanic slab down to $500 \mathrm{~km}$ depth, from the eastern Alps to the Aegean arc, along the southwestern margin of the Dinarides. In the west, these remnants start from north of the Istria Peninsula and run parallel to the eastern shoreline of the Adriatic Sea (Figs. 1 and 2). The velocity anomaly interpreted as a cool, subducted oceanic slab seems to be located more and more northeastward with increasing depth, which is in agreement with a northeastdipping former subducted slab. The surface projection of the velocity anomaly coincides with the supposed trace of the Budva trough, a long-lasting, deep, and mobile zone of the Dinarides with major Paleogene deformation and flysch deposition (Dimitrijević, 1982; Pamić, 1984). However, with a few exceptions (e.g., Csontos and Vörös, 2004), most authors do not regard the Budva zone as a trace of a potential ocean.

Lippitsch et al. (2003) concluded that the direction of subduction changes beneath the eastern Alps, somewhere beneath the Giudicarie zone, where the southward-dipping subduction of the European margin is relayed by the northward-directed subduction of the Apulian indenter. The remnants of the subducted slab can be detected down to a depth of $300 \mathrm{~km}$. The northward-directed cool slab may be a continuation of the "Budva" slab identified by Wortel and Spakman (2000) and Koulakov et al. (2002). Subduction along the Budva zone, as indicated by tomographic studies, is parallel and close enough to the Paleogene-early Miocene igneous series of the Periadriatic zone (only for the easternmost members) and Sava-Vardar zone to be a viable magmatic source. By contrast, the present position of the subducted slab along the Budva zone is not proximal enough to explain the formation of igneous rocks along the Mid-Hungarian zone.

As proposed already, both the Paleogene-early Miocene igneous suite and mantle rocks from west Hungary and from east Serbia require the vicinity (i.e., max. 100-150 km) of a subducted oceanic slab. Given the concomitant timing and chemical characteristics of all the Paleogene-early Miocene magmatic rocks, and considering the nature of the orthopyroxene-rich mantle xenoliths, we speculate that all geochemical, geodynamic, and geochronological characteristics may be explained by a single subduction event. In the following, we list geological evidence of known or potential subduction scars in the region and consider those that may have been responsible for the generation of the Paleogene-early Miocene magmatites.

\section{DISCUSSION}

\section{Possible Subduction Zones}

Three oceans have been suggested to have existed in the Adriatic-European area in the Paleogene: the Piedmont-LigurianPenninic-Váh (-Magura) Ocean (Csontos, 1995; Channell and Kozur, 1997; Nemcok et al., 1998), the Vardar Ocean (Channell and Kozur, 1997; Pamić et al., 2002b), and the Budva-Pindos Ocean (Csontos and Vörös, 2004) (Fig. 2). The suture of the Penninic Ocean was located north of the Paleogene-early Miocene igneous rocks. The suture of the Vardar Ocean coincides with the southern part of the present-day locus of the magmatic belt, and the proposed Budva Ocean was located to the south. In all three cases, the trace of these potential sutures is not compatible with the present-day diverging shape of the Paleogene-early Miocene igneous belt (Fig. 2).

In the Carpathians, most of the subduction-related shortening occurred during the early and middle Miocene (Meulenkamp et al., 1996; Nemcok et al., 1998) and was balanced by 
backarc basin extension (Horváth, 1993). However, there are some signs of earlier, Eocene subduction (Oszczypko, 1992). The present contours of this subduction along the Carpathians are apparently geometrically unrelated to the shape of the Paleogene igneous rocks of study area, especially to the Sava-Vardar zone. In the Alps, however, the Penninic Ocean that subducted southeastward is the only known candidate to account for the formation of the Paleogene plutons along the western Periadriatic zone (Kagami et al., 1991; von Blanckenburg et al., 1998). This is especially true of plutons situated west of the Giudicaria line (Biella, Bergell, Adamello) (Fig. 1). In the eastern continuation, the southward-directed subduction of the Magura Ocean was located too far north and was also too young to explain the genesis of the Mid-Hungarian zone and Sava-Vardar zone Paleogene magmatic rocks.

A potential ocean could have been located within the SavaVardar belt (Pamić, 1998). This and the adjoining structural belts host large amounts of obducted ultramafic-mafic material of Jurassic (and partly Triassic) age. Obduction of this Mesozoic oceanic lithosphere occurred in the Late Jurassic times (Dimitrijević, 1997; Pamić et al., 2002b). Other arguments, for example, the presence of huge exotic granite blocks (Pamić and Tomljenović, 2000) within Early Cretaceous postobduction clastics, strongly suggest that the ocean that formed the obducted ophiolite sheet was closed by Early (or at latest Middle) Cretaceous. However, in the SavaVardar zone, there are some limited basalt occurrences of Late Cretaceous age (Karamata et al., 1999; Cvetković et al., 2004a), which leave open the possibility of a small Late Cretaceous ocean (see also Pamić et al., 2002b). This possibility is amplified by the large amount of Late Cretaceous-Paleogene turbidites within the same zone (Jelaška, 1978). As has already been stated, there are igneous rocks from the Cretaceous in the Sava-Vardar zone (Pamić and Balen, 2001; Cvetković et al., 2004a) that are intruded in or are interlayered with turbiditic rocks of the Sava-Vardar belt (Čanović and Kemenici, 1987; Pamić et al., 1998). In their tectonic model, Pamić et al. (1998) suggested a Late Jurassic obduction, followed by continuous Late Cretaceous-Paleogene subduction beneath the northern Tisza plate. In this model, Late Cretaceous and Paleogene magmatic rocks are derived from the subduction of this Late Cretaceous Vardar Ocean (Fig. 2).

There are, however, several problems with this model. Putting aside strong arguments of Early Cretaceous collision (see details in Csontos and Vörös, 2004), it is very difficult to conceive of an island arc continuously located within the potential accretionary prism (Sava-Vardar turbidites) or even on the lower plate over a $40 \mathrm{~m}$.y. time span. This could only be possible if the slab was subvertical for 40 m.y. Another major problem with this model is that seismic tomography reveals no trace of such a slab (Spakman, 1990; Koulakov et al., 2002). Paleogene-early Miocene igneous rocks in the Sava-Vardar zone are located both east and west of this hypothetic suture zone (Fig. 2), which makes their origin from a former Vardar Ocean even more unlikely.

The third potential ocean could be related to the Budva (-Pindos) belt. In the late Eocene-Oligocene (Pamić and
Tomljenović, 2000), this tectonic unit was at the origin of voluminous turbidites thrusted onto the southern, Adriatic margin, all along the Adriatic coast. Budva is not considered to be an oceanic realm by many authors, simply because it does not host ophiolites. However, the seismic tomographic proof of a subducted slab coinciding with the supposed Budva trough strongly suggests that Budva (and the Pindos belt in its continuation) was a long-lived Mesozoic ocean that subducted during the Late Cretaceous(?)-Paleogene and was closed by the early Miocene (i.e., in the same time interval required to generate the Paleogene-early Miocene magmatites). The trace of this potential scar is at an appropriate distance from the Sava-Vardar zone magmatic arc to generate subduction-related igneous rocks. It fails, however, to explain the Periadriatic zone (especially its western segment), since the slab ends (and ended: see Schmid et al., 2004) southeast of most Periadriatic zone magmatic occurrences. It lies very distant from the Mid-Hungarian zone and also mantle xenoliths of western Hungary in their present position; moreover, the geometry is totally discordant.

In summary, none of the three known or inferred Paleogene subduction zones can give an unambiguous and single solution for the generation of our subduction-related magmatic rocks and orthopyroxene-rich mantle rocks in their present position; therefore, a tectonic reconstruction is needed that considers major tectonic changes from the Paleogene to the present day.

\section{Tectonic Events}

Based on numerous structural studies and tectonic reconstructions (Balla, 1984; Csontos, 1995; Fodor et al., 1999; Csontos et al., 2002), the study area was formed throughout three major steps in the Tertiary. The earliest Tertiary tectonic phase took place in the Paleogene as a major right-lateral shear event along the Periadriatic zone, the Balaton fault, and in the Internal Dinarides (Fig. 6). This shear event was initiated in the late Eocene (Fodor et al., 1992), but the bulk of shearing appears to have occurred during the Oligocene. As a consequence, Alcapa was subject to major right-lateral displacement during the Paleogene (Kázmér and Kovács, 1985).

The intermediate Tertiary tectonic phase was dominated by opposite rotations of two microplates within the CarpathianPannonian region: Alcapa and Tisza-Dacia (Márton, 1987; Csontos et al., 2002). Based on paleomagnetic data from Paleogene-early Miocene rocks (Márton, 1987), the two microcontinents were detached from their southern neighbor, the Dinarides, and were pushed/rotated into the formerly existing Carpathian embayment during the early Miocene (ca. 20-18 Ma) (Fig. 6).

The last, middle Miocene to subrecent tectonic phase is that of arc formation along the Carpathian chain. This event was coupled with major backarc basin formation. This tectonic phase is supposed to have been driven by the southward and westward subduction of the European margin beneath the internal Carpathian area (Balla, 1984; Horváth, 1993). This phase still shapes the area today, although with decreasing amplitude (Horváth, 1993; Csontos, 1995; Csontos et al., 2002). 


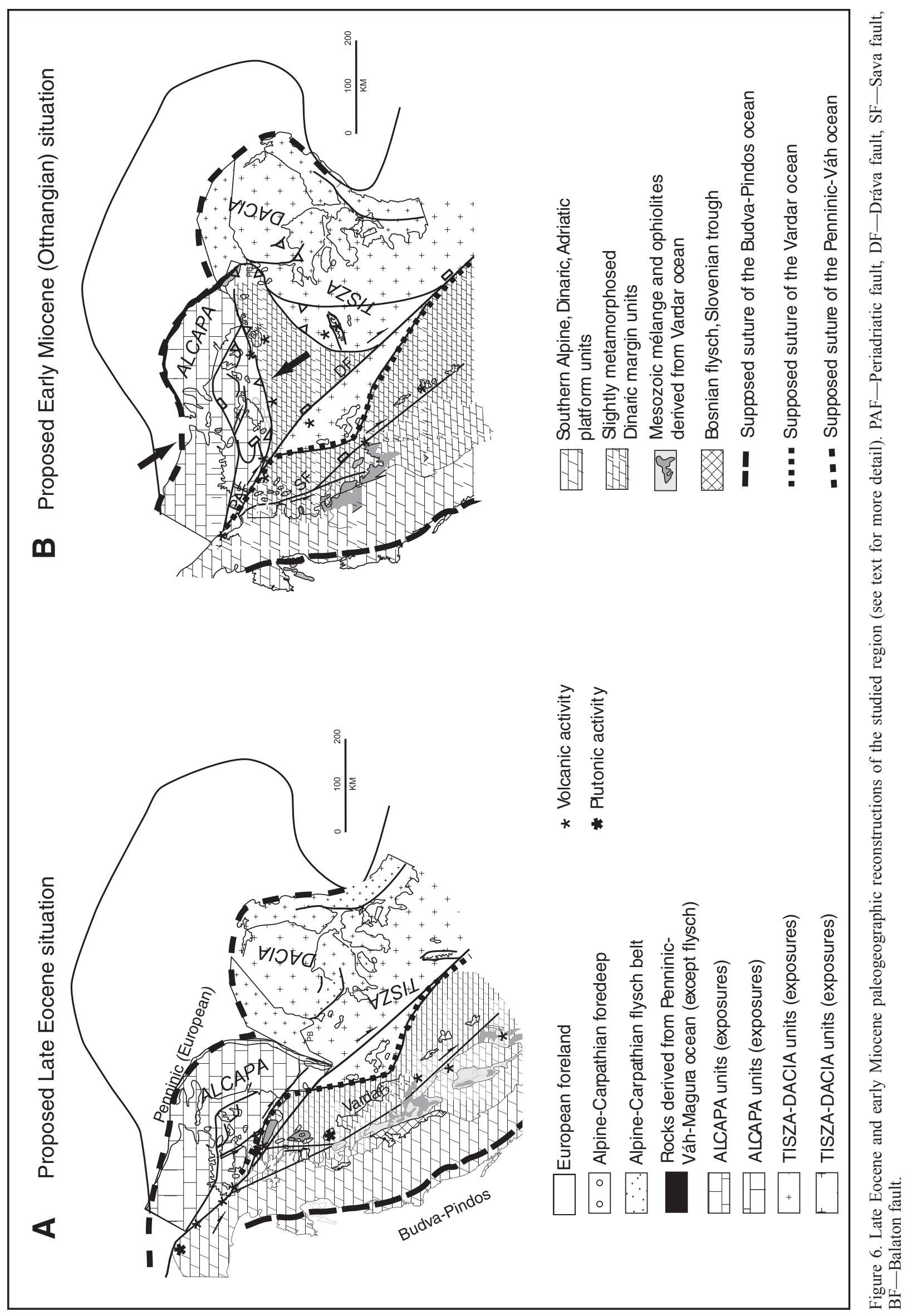




\section{Reconstruction of the Paleogene- Early Miocene Magmatic Arc}

The geochemistry, petrology, and age span of rocks in the Mid-Hungarian zone (Figs. 3, 4, and 5) strongly argue for a close link with their counterparts in both the Periadriatic zone and Sava-Vardar zone. As stated already and shown on Figure 2, the country rocks are of Internal Dinaric origin in both the MidHungarian zone and in the Sava-Vardar zone. Several correlation studies have proven that the same formations are present as carrier rocks with similar deformation histories (e.g., Pamić and Tomljenović, 1998; Csontos, 1999; Tomljenovic and Csontos, 2001; Filipović et al., 2003). Some rocks along the Periadriatic fault are easily correlated to similar rocks of the Balaton fault (Fodor et al., 1998; Haas et al., 2000) and to smaller massifs (Szendrö-Uppony) in north Hungary (Ebner et al., 1998). The truncated North Hungarian Paleogene basin, with locally voluminous tuffs, has a counterpart in the also-truncated Slovenian Paleogene basin (Csontos et al., 1991) (Fig. 2).

Rock series of the northern Mecsek zone may correlate with the Papuk Mountains exposures in Croatia (Kovács et al., 2000) (Fig. 2). The stratigraphic equivalents of Szolnok-Maramures flysch turbidites have been proposed to occur in the most internal, northern part of the Dinarides, in the Pozega, Psunj, and Motajica Mountains (Fig. 2) in the Sava-Vardar zone (Pamić et al., 1998). In conclusion, not only the Paleogene-early Miocene magmatic rocks, but also their country rocks departed from the general NW-SE trend of the Sava-Vardar (and Periadriatic) zone (Fig. 2). The question remains: How can this geometry have been achieved?

Previous studies have suggested that backarc extension, major rotation, and right-lateral shear may have all contributed to the present large offsets and divergent forms in the region. Tari (1994), Kováć et al. (1998), Fodor et al. (1999), and Tari et al. (1999) have all made rough reconstructions of the middle Miocene to subrecent extension. Taking those stretching values ( 1.5-1.8 beta factor) into consideration, the Mid-Hungarian zone still strongly departs from the strike of the Periadriatic zone and Sava-Vardar zone. If we also consider rotations given by paleomagnetic studies (Márton, 1987; Csontos et al., 2002), the Mid-Hungarian zone must have changed its shape and position, together with the strongly rotating Alcapa and Tisza-Dacia blocks. Such rotational reconstructions have been already proposed by Balla (1984), Márton and Fodor (1995), Kováć et al. (1998), and Csontos et al. (2002). Here, we performed a rough reassembly of all differently moving and rotating parts for the early Miocene and the Eocene based on paleomagnetic measurements (Fig. 6). The retro-rotation deformed mostly the MidHungarian zone, because it was squeezed between the more rigid Alcapa and Tisza-Dacia blocks. It was also somewhat attached to the two former units; therefore, their opposite rotation resulted in NE-SW stretching and NW-SE shortening of the Mid-Hungarian zone. This complex deformation can be demonstrated at several sites of the Mid-Hungarian zone (Balla, 1987; Csontos and
Nagymarosy, 1998; Csontos et al., 2005) in the age interval of the major rotations (latest Oligocene-early Miocene). In consequence, the Paleogene-early Miocene magmatic rocks of the Mid-Hungarian zone should be relocated near the junction of the Mid-Hungarian zone-Periadriatic zone-Sava-Vardar zone, in the Internal Dinarides (somewhere near Zagreb) (Fig. 6).

If such a reconstruction is accepted, the Periadriatic, the MidHungarian, and the Sava-Vardar Paleogene-early Miocene magmatic zones formed a single, linear and narrow belt and shared a common basement (Fig. 6). Assuming that the major blocks of Alcapa and Tisza-Dacia rotated together (at least partially) with their lithospheric mantle, the source region of the west Hungarian orthopyroxene-rich websterite mantle domain may have been close to the narrow Paleogene magmatic arc. Nevertheless, similar mantle xenoliths and their carrier rocks in east Serbia, as we have shown already, are still somewhat distal from this Paleogene arc, farther east from its main strike (Figs. 1 and 2).

\section{Speculations on the Subduction-Related Origin of the Paleogene Magmatic Arc}

The subduction of the European slab beneath the AlpineCarpathian-Dinaric system still cannot account for the whole of the reconstructed Paleogene magmatic arc. This subduction could well explain the Periadriatic magmatism (especially west of the Giudicaria line; Figs. 1 and 2); however, it cannot account for the rest of the arc. The reasons for this include: (1) quite different geometry of the proposed Paleogene-early Miocene arc; (2) the long distance from the proposed arc (even in reconstructed positions); and (3) the bulk of subduction along the Western Carpathians occurred after the early Miocene, which is inconsistent with the mainly Paleogene age of the arc volcanics.

The Pindos-Budva Ocean is documented on the surface near the southern tip of the Dinarides (Albania) (Fig. 2; Csontos and Vörös, 2004). It is proven at depth by seismic tomography as far as the Giudicaria line. Budva-Pindos subduction, therefore, might have been linear and roughly parallel to the Paleogene magmatic arc (Fig. 1). Although the suture of the Budva-Pindos Ocean is at an appropriate distance (100-120 km) to explain the subductionrelated rocks of the reconstructed Mid-Hungarian and Sava-Vardar magmatic arc (Fig. 6), it fails to explain all the Periadriatic magmatic rocks (especially the westernmost ones: Adamello, Bergell). The supposed suture of the Late Cretaceous-Paleogene Vardar Ocean coincides with, or is located somewhat to the east of, the Paleogene magmatic belt (Fig. 1). This puts into question Vardar subduction as a potential source of voluminous Paleogene-early Miocene igneous rocks in the Sava-Vardar zone. At the same time, the east Serbian mafic alkaline rocks and their orthopyroxene-rich websterite xenoliths, as well as the orthopyroxene-rich xenoliths of western Hungary that represent the lithospheric mantle, are at an appropriate distance $(\sim 100 \mathrm{~km})$ and are in a forearc setting relative to the trace of the Vardar suture in their reconstructed position. Therefore, their formation may be better explained by the Vardar subduction than that of the Budva-Pindos. 
In conclusion, it seems that the Paleogene-early Miocene igneous belt and the orthopyroxene-rich mantle xenoliths cannot be satisfactorily explained by one single subduction zone. In a working hypothesis, we propose that the orthopyroxene-rich websterite xenoliths were generated by subduction of the Vardar Ocean, and were then trapped in the mantle from which they were sampled by different volcanic events. In this respect, the Vardar subduction could have happened and ended well before the Paleogene; consequently, the xenoliths define only a lower age limit (i.e., before Paleogene).

Considering that the Budva-Pindos subduction zone is proven by tomography and also that it is at an appropriate distance from most of the reconstructed volcanic arc, we speculate that this was the subduction that generated the bulk of the Paleogene magmatic arc. The plutons at the eastern part of the Periadriatic zone could have been produced by a Budva-Pindos subduction event that might have reached as far as the Giudicaria line in the Alps. On the other hand, the plutons on the western portion of the Periadriatic zone can be explained by the Penninic (European slab) subduction. In other words, a relay of subduction zones is proposed (Fig. 7). The Africa-Europe shortening was possibly accommodated by the subduction of the European slab and nappe stacking in the Alps. This shortening could have been transferred to the Budva-Pindos subduction, because no major shortening occurred at the European slab in the Carpathians (Fig. 7). In this way, the two oppositely dipping and synchronous subductions could possibly explain the synchronicity and common subduction-related geochemical features of the Paleogene arc.

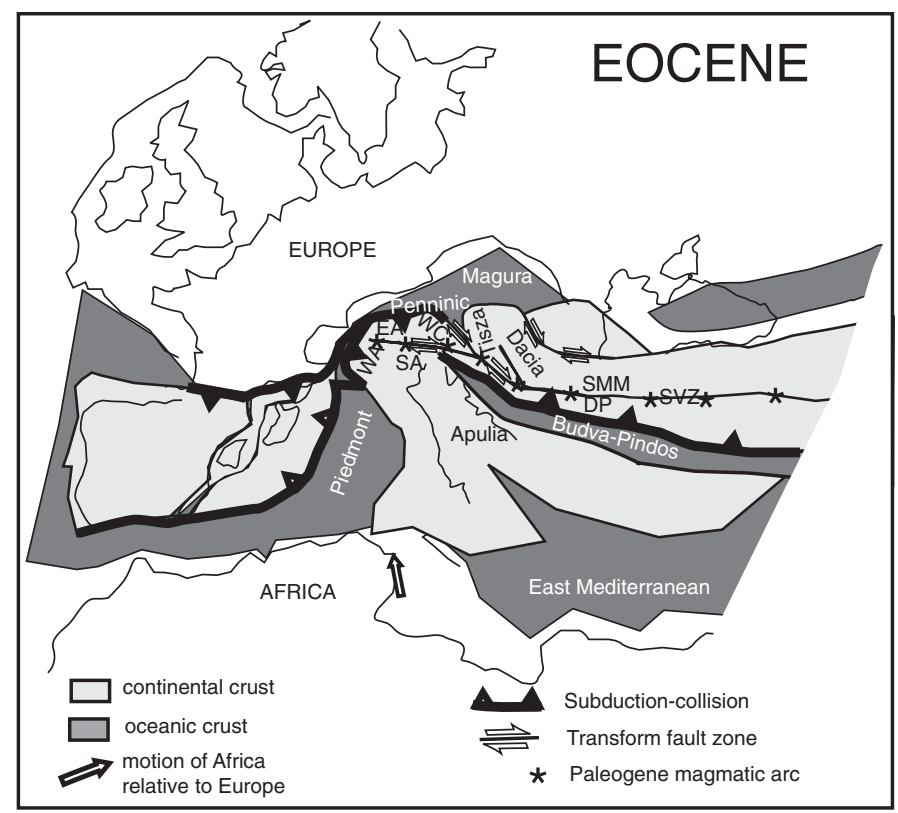

Figure 7. Early Eocene plate-tectonic sketch for the Mediterranean area (see text for more detail) (modified after Csontos and Vörös, 2004). WA-western Alps, EA — eastern Alps, WC-Western Carpathians, SA - southern Alps, DP—Dinaric Platform, SMM-SerboMacedonian massif.

\section{Speculations on Some Further-Reaching Implications of Tectonics and Magmatism}

The proposed late Eocene-early Oligocene magmatic belt (including the Mid-Hungarian zone in a reconstructed position) was affected by arc-parallel right-lateral slip from the late Eocene onward. The culmination of this right-lateral motion occurred in the Oligocene (see Figs. 6A and 6B). It is not clear whether the igneous activity was initiated by the major shear along the magmatic belt, or vice versa, if the deformation was made possible by the igneous activity. If a plate has been fractured at a zone of pre-existing weakness, lateral shear generates fractures and vents for the rising subduction-generated magma. If opposite and synchronous subduction of the Penninic and Budva-Pindos slabs is accepted, the linearity of the arc could have been generated by the shear belt. In other words, location of the Paleogene arc may have been largely controlled by tectonic features.

On the other hand, if the rising magma softened the upper plate, the heat impulse could have localize deformation. For example, the ductile behavior of the Mid-Hungarian unit during opposite rotation might be explained by the same softening due to higher heat flux related to magma infiltration.

Late Oligocene-early Miocene igneous rocks were also generated along the same belt and their formation was contemporaneous with the major block rotations. Consequently, these rocks were significantly displaced from their original position. Thus, it is also likely that their basement could have moved together with their respective mantle lithosphere, because subductionrelated geochemistry of igneous rocks still persisted. This may imply that the uppermost (lithospheric) mantle moves together with the crust during major block rotations, and should preserve its metasomatic components inherited from a previous geodynamic setting. Falus (2004) suggested that the Alcapa block (and its subunits) (Fig. 1) is a tectonic unit that moved together with its lithospheric mantle, because peridotite xenoliths from western Hungary display deformation patterns that show evidence of multiple deformation events. Xenoliths bear not only the deformation pattern related to the Miocene basin formation, but they also preserve traces of an older deformation event that is only characteristic for the shallower upper mantle. The preservation of orthopyroxene-rich websterite xenoliths from west Hungary and east Serbia (Fig. 1) (Bali, 2004; Cvetković et al., 2004b; Bali et al., 2004, 2006) in the uppermost lithospheric mantle may also confirm its common behavior during tectonic processes. Cesare et al. (2002) came to a similar conclusion about the formation of Carboniferous ultramafic cumulates of the SW Tauern window, because its source also had been metasomatized in a previous, distant tectonic setting and subsequently was displaced.

\section{CONCLUSIONS}

1. The Paleogene-early Miocene igneous suite in all studied igneous provinces of the Alps, Carpathians, and Dinarides was formed in the same time interval, with three peak episodes of 
magmatic activity in the Eocene, late Eocene-early Oligocene, and late Oligocene-early Miocene. The studied rocks have similar geochemistry and petrology, which show a subductionrelated character.

2. The magmatic belt along the Periadriatic zone can be followed along the Balaton fault, on the northern margin of the MidHungarian zone to the Bükk Mountains, N Hungary. This continuity is supported by well-correlated Mesozoic and Paleogeneearly Miocene rock assemblages that form the basement of these magmatic bodies. On the other hand, these N Hungarian country rocks have their counterparts in the internal zone of the Dinarides, along the Sava-Vardar zone, which also hosts similar magmatic rocks. We therefore suggest that all the Paleogene-early Miocene magmatic rocks of the studied region are closely related and have a common, subduction-related origin.

3. The present occurrence of these magmatic rocks in three separate, divergent zones is due to later tectonic events. These zones were mainly dispersed by the opposite rotations of the two main blocks, Alcapa and Tisza-Dacia, during the early Miocene. Reconstruction of these paleomagnetically proven rotations brings the three magmatic zones into a continuous, linear igneous belt of more than $1200 \mathrm{~km}$.

4. Rare orthopyroxene-rich websterite mantle xenoliths hosted in mafic rocks of separate areas as west Hungary and east Serbia have common petrographic and geochemical signatures. These mantle rocks must have formed close to a subduction event in a forearc setting. The closest subduction scar to both occurrences is that of the Vardar Ocean. This subduction terminated in the Late Jurassic (-Early Cretaceous); hence, these special subduction-related mantle rocks were trapped in the mantle.

5. The Paleogene magmatic arc was strongly affected by lithospheric-scale, arc-parallel, right-lateral strike-slip shear. This shear was initiated in the late Eocene, but maximum motion was achieved during the Oligocene. The fault-induced pervasive fracturing could have localized magmatic activity, and vice versa, the heat impulse of the magmatic activity could have rheologically softened the country rocks and rendered them more easily deformable. This second case is strongly suggested for the MidHungarian zone, which must have experienced highly intense deformations during the early Miocene rotations.

6. The Paleogene-early Miocene arc cannot be explained by a single subduction event. Instead, we propose that the western portion of igneous rocks in the Periadriatic zone is related to the Penninic subduction, whereas most of their Paleogene-early Miocene counterparts in the Mid-Hungarian zone and Sava-Vardar zone could have originated from the Budva Pindos subduction. The most likely solution is that these oppositely dipping and synchronous subductions relayed on each other and together accommodated the Europe-Africa convergence during the Paleogene.

7. The occurrences of late Oligocene-early Miocene magmas match with those of the late Eocene-early Oligocene igneous rocks. We speculate that the genesis and ascent of late Oligoceneearly Miocene magmas were initiated when the rotations took place. Thus, the rotated blocks could have also brought their earlier metasomatized lower lithosphere into the Carpathian embayment. The large volume of early Miocene magmatic rocks associated with the Mid-Hungarian zone also suggests that the ascent of these magmas was controlled or facilitated by the most deformed part of this structural zone. The normal faults and stretching of this zone could have played an important role in melting and also could have provided vents for the rising magma.

\section{ACKNOWLEDGMENTS}

We dedicate this work to the memory of the late Jakob Pamić. He visited us in his last year and initiated the quest for understanding the Tertiary igneous activity and its geodynamic framework in the region. He also wished to pass on his outstanding petrographic and general geological knowledge to all concerned geologists of the young generation.

The thorough review of Stefan Schmid is also appreciated. His comments are all the more appreciated, since he expressed his strong objections to many ideas developed in the text. Modifications in our model are in great part due to his remarks. Hilary Downes and Orlando Vaselli also provided us with helpful critical remarks and directed our attention to some overlooked igneous occurrences, which have great relevance for our purposes. They also pointed out the possible link of special xenoliths. We also thank Hilary Downes and Nick Tailby for polishing our Hunglish. I. Kovács is grateful to Jörg Hermann and Hugh St. C. O’Neill for their patience and encouragement during the preparation of the revised manuscript. Finally, the help and patient editorial approach of Luigi Beccaluva and Gianluca Bianchini are highly appreciated. Without the encouragement of Luigi Beccaluva, this work could not have reached press. The work was supported by OTKA T043686 grant to Cs. Szabó and OTKA T043760 grant to L. Csontos. This work was partially supported by an A.E. Ringwood Memorial Scholarship and an Australian International Postgraduate Research Scholarship to I. Kovács. This is publication 26 in the series of the Lithosphere Fluid Research Laboratory at Eötvös University, Budapest, Hungary.

\section{REFERENCES CITED}

Altherr, R., Lugovic, B., Meyer, H.P., and Majer, V., 1995, Early-Miocene postcollisional calc-alkaline magmatism along the easternmost segment of the Periadriatic fault system (Slovenia and Croatia): Mineralogy and Petrology, v. 54, no. 3-4, p. 225-247, doi: 10.1007/BF01162863.

Aubouin, J., Blanchet, R., Cadet, P., Celet, P., Charvet, J., Chorowitz, J., Cousin, M., and Rampnoux, J.-P., 1970, Essai sur la geologie des Dinarides: Bulletin de la Société Géologique de France, v. XII, no. 6, p. 1060-1095.

Bali, E., 2004, Fluid/melt-wall rock interaction in the upper mantle beneath the central Pannonian Basin [Ph.D. thesis]: Eötvös, Lithosphere Fluid Research Lab, Eötvös University, 165 p.

Bali, E., Szabó, C., Peate, D.W., Falus, G., Török, K., and Ntaflos, T., 2006, Remnants of boninitic melts in the upper mantle beneath the central Pannonian Basin? The significance of orthopyroxene-rich websterite veins in peridotite xenoliths: Mineralogy and Petrology (in press).

Balla, Z., 1984, The Carpathian loop and the Pannonian basin: Kinematic analysis: Geophysical Transactions, v. 30, no. 4, p. 313-353.

Balla, Z., 1987, Tertiary paleomagnetic data for the Carpatho-Pannonian region in the light of Miocene rotation kinematics: Tectonophysics, v. 139, no. 1-2, p. 67-98, doi: 10.1016/0040-1951(87)90198-3. 
Barnes, S.J., and Roeder, P.L., 2001, The range of spinel compositions in terrestrial mafic and ultramafic rocks: Journal of Petrology, v. 42, no. 12, p. 2279-2302, doi: 10.1093/petrology/42.12.2279.

Benedek, K., 2002, Paleogene igneous activity along the easternmost segment of the Periadriatic-Balaton lineament: Acta Geologica Hungarica, v. 45, no. 4, p. 359-371, doi: 10.1556/AGeol.45.2002.4.3.

Benedek, K., 2003, Petrogenetic investigation of Paleogene calk-alkaline igneous rocks penetrated in the Zala Basin, Hungary [Ph.D. thesis]: Eötvös, Lithosphere Fluid Research Lab, Eötvös University, 122 p.

Benedek, K., Nagy, Z.R., Dunk1, I., Szabó, C., and Józsa, S., 2001, Petrographical, geochemical and geochronological constraints on igneous clasts and sediments hosted in the Oligo-Miocene Bakony Molasse, Hungary: Evidence for a paleo-Drava River system: International Journal of Earth Sciences, v. 90, no. 3, p. 519-533, doi: 10.1007/s005310000183.

Benedek, K., Pécskay, Z., Szabó, C., Jósvai, J., and Németh, T., 2004, Paleogene igneous rocks in the Zala Basin (western Hungary): Link to the Paleogene magmatic activity along the Periadriatic lineament: Geologica Carpathica, v. 55, no. 1, p. 43-50.

Brügel, A., Dunkl, I., Frisch, W., Kuhlemann, J., and Balogh, K., 2000, The record of Periadriatic volcanism in the eastern Alpine Molasse zone and its palaeogeographic implications: Terra Nova, v. 12 , no. 1, p. 42-47, doi: 10.1046/j.1365-3121.2000.00269.x.

Čnović, M., and Kemenici, R., 1987, The Mesozoic of the Pannonian Basin in Vojvodina: Novi Sad, Matica Srpska: Novi Sad, 334 p.

Cesare, B., Rubatto, D., Hermann, J., and Barzi, L., 2002, Evidence for Late Carboniferous subduction-type magmatism in mafic-ultramafic cumulates of the SW Tauern window (eastern Alps): Contributions to Mineralogy and Petrology, v. 142, no. 4, p. 449-464.

Channell, J.E.T., and Kozur, H.W., 1997, How many oceans? Meliata, Vardar, and Pindos oceans in Mesozoic Alpine paleogeography: Geology, v. 25 , no. 2 , p. 183-186, doi: 10.1130/0091-7613(1997)025<0183: HMOMVA $>2.3 . \mathrm{CO} ; 2$

Csontos, L., 1995, Tertiary tectonic evolution of the Intra-Carpathian area: A review: Acta Vulcanologica, v. 7, p. 1-13.

Csontos, L., 1999, Structural outline of the Bükk Mts. (N-Hungary): Bulletin of the Hungarian Geological Society, v. 129, no. 4, p. 611-651.

Csontos, L., and Nagymarosy, A., 1998, The mid-Hungarian line: A zone of repeated tectonic inversions: Tectonophysics, v. 297 , no. $1-4$, p. $51-71$, doi: 10.1016/S0040-1951(98)00163-2.

Csontos, L., and Vörös, A., 2004, Mesozoic plate tectonic reconstruction of the Carpathian region: Palaeogeography, Palaeoclimatology, Palaeoecology, v. 210 , no. 1, p. 1-56, doi: 10.1016/j.palaeo.2004.02.033.

Csontos, L., Tari, G., Bergerat, F., and Fodor, L., 1991, Evolution of the stressfields in the Carpatho-Pannonian area during the Neogene: Tectonophysics, v. 199, no. 1, p. 73-91, doi: 10.1016/0040-1951(91)90119-D.

Csontos, L., Márton, E., Wórum, G., and Benkovics, L., 2002, Geodynamics of SW-Pannonian inselbergs Mecsek and Villány Mts., SW Hungary: Inferences from a complex structural analysis: European Geophysical Union Stephan Mueller Publication Series, v. 3, p. 1-19.

Csontos, L., Magyari, Á., VanVliet-Lanoë, B., and Musitz, B., 2005, Neotectonics of the Somogy hills (Part II): Evidence from seismic sections: Tectonophysics, v. 410, p. 63-80.

Cvetković, V., Prelevic, D., Downes, H., Jovanovic, M., Vaselli, O., and Pécskay, Z., 2004a, Origin and geodynamic significance of Tertiary postcollisional basaltic magmatism in Serbia (central Balkan Peninsula): Lithos, v. 73, no. 3-4, p. 161-186, doi: 10.1016/j.lithos.2003.12.004.

Cvetković, V., Downes, H., Prelević, D., Jovanović, M., and Lazarov, M., 2004b, Characteristics of the lithospheric mantle beneath east Serbia inferred from ultramafic xenoliths in Palaeogene basanites: Contributions to Mineralogy and Petrology, v. 148 , no. 3, p. 335-357, doi: $10.1007 /$ s00410-004-0607-x.

Dal Piaz, G.V., and Gosso, G., 1993, Some remarks on evolution of the Alpine lithosphere: Quaderni Geodinamica Alpina et Quaternarica, v. 2, p. 93 101.

Dimitrijević, M.D., 1982, Dinarides: An outline of the tectonics: Earth Evolution Science, v. 2, no. 1, p. 4-23.

Dimitrijević, M.D., 1997, Geology of Yugoslavia: Beograd, Geological Institute Gemini Special Publication, $187 \mathrm{p}$.

Dobosi, G., Downes, H., Embey-Isztin, A., and Jenner, G.A., 2003a, Origin of megacrysts and pyroxenite xenoliths from the Pliocene alkali basalts of the Pannonian Basin (Hungary): Neues Jahrbuch für MineralogieAbhandlungen, v. 178, no. 3, p. 217-237, doi: 10.1127/0077-7757/2003/ 0178-0217.
Dobosi, G., Kempton, P.D., Downes, H., Embey-Isztin, A., Thirlwall, M., and Greenwood, P., 2003b, Lower crustal granulite xenoliths from the Pannonian Basin, Hungary, Part 2: Sr-Nd-Pb-Hf and $\mathrm{O}$ isotope evidence for formation of continental lower crust by tectonic emplacement of oceanic crust: Contributions to Mineralogy and Petrology, v. 144, no. 6, p. 671-683.

Downes, H., Embey-Isztin, A., and Thirlwall, M.F., 1992, Petrology and geochemistry of spinel peridotite xenoliths from the western Pannonian Basin (Hungary) - Evidence for an association between enrichment and texture in the upper mantle: Contributions to Mineralogy and Petrology, v. 109, no. 3, p. 340-354, doi: 10.1007/BF00283323.

Downes, H., Vaselli, O., Segedhi, I., Ingram, G., Rex, D., Cardossi, N., Pécskay, Z., and Pinarelli, L., 1995a, Geochemistry of Late Cretaceous-early Tertiary magmatism in Poiana Rusca (Romania): Acta Vulcanologica, v. 7, no. 2, p. 209-217.

Downes, H., Pantó, G., Póka, T., Mattey, D.P., and Greenwood, P.B., 1995b, Calc-alkaline volcanics of the Inner Carpathian arc, northern Hungary: New geochemical and oxygen isotopic results: Acta Vulcanologica, v. 7, no. 2, p. 29-41.

Dunkl, I., and Nagymarosy, A., 1990, New data to the age of the Eocene/ Oligocene boundary: Fission track study on tuff layers of the Lower Oligocene Tard Clay: Általános Földtani Szemle, v. 25, p. 151-162.

Dunkl, I., and Nagymarosy, A., 1992, A new tie-point candidate for the Paleogene timescale calibration: Fission track dating of tuff layers of Lower Oligocene Tard Clay (Hungary): Neues Jahrbuch für Geologie und Paläontologie Abhandlungen, v. 186, p. 345-364.

Ebner, F., Kovács, S., and Schönlaub, H.P., 1998, Stratigraphic and facial correlation of the Szendrö-Uppony Palaeozoic (NE Hungary) with the Carnic Alps-Southern Karawanken Mts. and Graz Palaeozoic (southern Alps and central eastern Alps); some paleogeographic implications: Acta Geologica Hungarica, v. 41, no. 4, p. 355-388.

Ellam, R.M., and Hawkesworth, C.J., 1988, Elemental and isotopic variations in subduction related basalts-Evidence for a 3 component model: Contributions to Mineralogy and Petrology, v. 98, no. 1, p. 72-80, doi: 10.1007/BF00371911.

Embey-Isztin, A., Dobosi, G., Altherr, R., and Meyer, H.P., 2001, Thermal evolution of the lithosphere beneath the western Pannonian Basin: Evidence from deep-seated xenoliths: Tectonophysics, v. 331, no. 3, p. 285-306, doi: 10.1016/S0040-1951(00)00287-0.

Embey-Isztin, A., Downes, H., and Kempton, P.D., 2003, Lower crustal granulite xenoliths from the Pannonian Basin, Hungary. Part 1: Mineral chemistry, thermobarometry and petrology: Contributions to Mineralogy and Petrology, v. 144, no. 6, p. 652-670.

Falus, G., 2004, Microstructural analysis of upper mantle peridotites: Their application in understanding mantle processes during the formation of the Intra-Carpathian Basin system [Ph.D. thesis]: Eötvös, Lithosphere Fluid Research Lab, Eötvös University, 140 p.

Filipović, I., Jovanović, D., Sudar, M., Pelikán, P., Kovács, S., Less, G., and Hips, K., 2003, Comparison of Variscan-early Alpine evolution of the Jadar Block (NW Serbia) and "Bükkium" (NE Hungary) terranes; some paleogeographic implications: Slovak Geological Magazine, v. 9, no. 1, p. $23-40$.

Fodor, L., Magyari, A., Kázmér, M., and Fogarasi, A., 1992, Gravity-flow dominated sedimentation on the Buda paleoslope (Hungary) - Record of late Eocene continental escape of the Bakony unit: Geologische Rundschau, v. 81 , no. 3, p. 695-716, doi: 10.1007/BF01791386.

Fodor, L., Jelen, B., Márton, E., Skaberne, D., Car, J., and Vrabec, M., 1998, Miocene-Pliocene tectonic evolution of the Slovenian Periadriatic fault: Implications for Alpine-Carpathian extrusion models: Tectonics, v. 17, no. 5, p. 690-709, doi: 10.1029/98TC01605.

Fodor, L., Csontos, L., Bada, G., Győrfi, I., and Benkoics, L., 1999, Tertiary tectonic evolution of the Pannonian Basin system and neighbouring orogens: A new synthesis of paleostress data, in Durand, B., Jolivet, L., Horváth, F., and Séranne, M., eds., The Mediterranean Basins: Tertiary Extensions within the Alpine Orogen: Geological Society of London Special Publication 156, p. 295-334.

Haas, J., Kovács, S., Krystyn, L., and Lein, R., 1995, Significance of Late Permian-Triassic facies zones in terrane reconstructions in the Alpine North Pannonian domain: Tectonophysics, v. 242, no. 1-2, p. 19-40, doi: 10.1016/0040-1951(94)00157-5.

Haas, J., Mioc, P., Pamic, J., Tomljenovic, B., Árkai, P., Bérczi-Makk, A., Koroknai, B., Kovács, S., and Felgenhauer, E.R., 2000, Complex structural pattern of the Alpine-Dinaridic-Pannonian triple junction: Inter- 
national Journal of Earth Sciences, v. 89, no. 2, p. 377-389, doi: 10.1007/ s005310000093.

Hámor, G., Ravasz-Baranyai, L., and Halmai, J., 1987, Dating of Miocene acidic and intermediate volcanic activity in Hungary, in Annals of the Hungarian Geological Institute, v. LXX, p. 149-154.

Harangi, S., 2001, Neogene to Quaternary volcanism of the Carpathian-Pannonian region-A review: Acta Geologica Hungarica, v. 44, p. 223-258.

Horváth, F., 1993, Towards a mechanical model for the formation of the Pannonian Basin: Tectonophysics, v. 226, no. 1-4, p. 333-357, doi: 10.1016/ 0040-1951(93)90126-5.

Jelaška, V., 1978, Senonian-Paleogene flysch of the Mt. Trebović area north Bosnia: Stratigraphy, and sedimentology: Zagreb, Geologica Vjesnik, p. 95-118.

Jovanović, M., Downes, H., Vaselli, O., Cvetković, V., Prelević, D., and Pécskay, Z., 2001, Paleogene mafic alkaline volcanic rocks of east Serbia: Acta Vulcanologica, v. 13, no. 1/2, p. 159-173.

Kagami, H., Ulmer, P., Hansmann, W., Dietrich, V., and Steiger, R.H., 1991, $\mathrm{Nd}-\mathrm{Sr}$ isotopic and geochemical characteristics of the southern Adamello (northern Italy) intrusives - Implications for crustal versus mantle origin: Journal of Geophysical Research, Solid Earth and Planets, v. 96, no. B9, p. $14,331-14,346$.

Karamata, S., Dimitrijević, N.M., and Dimitrijević, M.D., 1999, Oceanic realms in the central part of the Balkan Peninsula during Mesozoic: Slovak Geological Magazine, v. 5, no. 3, p. 173-177.

Kázmér, M., and Kovács, S., 1985, Permian-Paleogene paleogeography along the eastern part of the Insubric-Periadriatic lineament system: Evidence for the continental escape of the Bakony-Drauzug unit: Acta Geologica Hungarica, v. 28 , no. 71-84.

Kázmér, M., Dunkl, I., Frisch, W., Kuhlemann, J., and Ozsvárt, P., 2003, The Palaeogene forearc basin of the eastern Alps and Western Carpathians: Subduction erosion and basin evolution: Journal of the Geological Society of London, v. 160, p. 413-428.

Koulakov, I., Tychkov, S., Bushenkova, N., and Vasilevsky, A., 2002, Structure and dynamics of the upper mantle beneath the Alpine-Himalayan orogenic belt, from teleseismic tomography: Tectonophysics, v. 358, no. 1-4, p. 77-96, doi: 10.1016/S0040-1951(02)00418-3.

Kováć, M., Nagymarosy, A., Oszczypko, N., Csontos, L., Slaczka, A., Marunteanu, M., Matenko, L., and Márton, E., 1998, Palinspastic reconstruction of the Carpathian- Pannonian region during the Miocene, in Rakuš, M., ed., Geodynamic Development of the Western Carpathians: Bratislava, Geologický ústav Dionýza Štúra, p. 198-217.

Kovács, I., and Szabó, C., 2005, Petrology and geochemistry of granulite xenoliths beneath the Nógrád-Gömör volcanic field, Carpathian-Pannonian region (N-Hungary-S-Slovakia): Mineralogy and Petrology, v. 85, p. 269-290, doi: 10.1007/s00710-005-0090-8.

Kovács, I., Zajacz, Z., and Szabó, C., 2004, Type-II xenoliths and related metasomatism from the Nógrád-Gömör volcanic field, Carpathian-Pannonian region (northern Hungary-southern Slovakia): Tectonophysics, v. 393 , no. 1-4, p. 139-161, doi: 10.1016/j.tecto.2004.07.032.

Kovács, S., Szederkényi, T., Haas, J., Hámor, G., and Nagymarosy, A., 2000, Tectonostratigraphic terranes in the pre-Neogene basement of the Hungarian part of the Pannonian area: Acta Geologica Hungarica, v. 43, no. 3 , p. 225-328.

Lakatos, L., Váradi, M., Pogácsás, G., Nagymarosy, A., and Barvitz, A., 1992, Sequence stratigraphic relations in the Zagyva trough: Magyar Geofizika, v. 32 , p. $20-37$.

Laubscher, H., 1983, The late Alpine Periadriatic intrusions and the Insubric Line: Memoire della Societa Geologica Italiana, v. 26, p. 21-30.

Less, G., 1999, A Mediterrán Paleocén-Eocén Orthophragmina-És a Tethys Tercier sekélybentosz-zonációja, 2: Noszvaj, Oslénytani Vándorgyülés, p. 13-14.

Less, G., 2000, Upper Paleogene larger foraminiferal assemblages from the Bükk Mountains (NE Hungary): Bucuresti, Anuarul Institutului Geolologic al Romaniei, p. 47.

Lippitsch, R., Kissling, E., and Ansorge, J., 2003, Upper mantle structure beneath the Alpine orogen from high-resolution teleseismic tomography: Journal of Geophysical Research, Solid Earth, v. 108, no. B8, 2376, doi: 10.1029/2002JB002016.

Márton, E., 1987, Paleomagnetism and tectonics in the Mediterranean region: Journal of Geodynamics, v. 7, no. 1-2, p. 33-57, doi: 10.1016/02643707(87)90062-7.

Márton, E., and Fodor, L., 1995, Combination of paleomagnetic and stress data-A case-study from north Hungary: Tectonophysics, v. 242, no. 1-2, p. 99-114, doi: 10.1016/0040-1951(94)00153-Z.
Mason, P.R.D., Seghedi, I., Szakács, A., and Downes, H., 1998, Magmatic constraints on geodynamic models of subduction in the East Carpathians, Romania: Tectonophysics, v. 297, no. 1-4, p. 157-176, doi: 10.1016/ S0040-1951(98)00167-X.

Máthé, Z., Fórizs, I., Tóth, M., and Polgári, M., 1997, Contributions to the clay mineralization and zeolitization of the Miocene tuffs in the Mecsek Mountains., Hungary: Geologica Carpathica, v. 6, no. 1, p. 47-55.

McDonough, W.F., and Sun, S.S., 1988, A primitive mantle composition from xenoliths: Chemical Geology, v. 70, no. 1-2, p. 12-12, doi: 10.1016/00092541(88)90208-2.

McInnes, B.I.A., Gregoire, M., Binns, R.A., Herzig, P.M., and Hannington, M.D., 2001, Hydrous metasomatism of oceanic sub-arc mantle, Lihir, Papua New Guinea: Petrology and geochemistry of fluid-metasomatised mantle wedge xenoliths: Earth and Planetary Science Letters, v. 188 , no. 1-2, p. 169-183, doi: 10.1016/S0012-821X(01)00306-5.

Melcher, F., Meisel, T., Puhl, J., and Koller, F., 2002, Petrogenesis and geotectonic setting of ultramafic rocks in the Eastern Alps: Constraints from geochemistry: Lithos, v. 65, no. 1-2, p. 69-112, doi: 10.1016/S0024-4937 (02)00161-5.

Meulenkamp, J.E., Kovac, M., and Cicha, I., 1996, On late Oligocene to Pliocene depocentre migrations and the evolution of the CarpathianPannonian system: Tectonophysics, v. 266, no. 1-4, p. 301-317, doi: 10.1016/S0040-1951(96)00195-3.

Nagymarosy, A., and Báldi-Beke, M., 1993, The Szolnok unit and its probable paleogeographic position: Tectonophysics, v. 226 , no. $1-4$, p. 457-470, doi: 10.1016/0040-1951(93)90132-4.

Nakamura, N., 1974, Determination of REE, Ba, Fe, Mg, Na and K in carbonaceous and ordinary chondrites: Geochimica et Cosmochimica Acta, v. 38, no. 5, p. 757-775, doi: 10.1016/0016-7037(74)90149-5.

Nédli, Z., and Tóth, M., 1999, Mantle xenolith in the mafic dyke at Beremend, Villány Mts., SW Hungary: Acta Mineralogica-Petrographica, v. 40, p. 97-104.

Nemcok, M., Pospisil, L., Lexa, J., and Donelick, R.A., 1998, Tertiary subduction and slab break-off model of the Carpathian-Pannonian region: Tectonophysics, v. 295 , no. 3-4, p. 307-340, doi: 10.1016/S00401951(98)00092-4.

Oszczypko, N., 1992, Late Cretaceous through Palaeogene evolution of the Magura basin: Geologica Carpathica, v. 43, p. 334-338.

Pamić, J., 1984, Triassic magmatism of the Dinarides in Yugoslavia: Tectonophysics, v. 109, no. 3-4, p. 273-307, doi: 10.1016/0040-1951(84)90145-8.

Pamić, J., 1998, North Dinaridic Late Cretaceous-Paleogene subductionrelated tectonostratigraphic units of southern Tisia, Croatia: Geologica Carpathica, v. 49 , no. 5 , p. 341-350.

Pamić,J., and Balen, D., 2001, Tertiary magmatism of the Dinarides and the adjoining south Pannonian Basin: An overview: Acta Vulcanologica, v. 13 , no. $1-2$, p. $9-24$.

Pamić, J., and Tomljenović, B., 1998, Basic geologic data from the Croatian part of the Zagorje-Mid-Transdanubian zone: Acta Geologica Hungarica, v. 41, p. $389-400$.

Pamić, J., and Tomljenović, B., 2000, Field trip guidebook of the Pannon-CarpathianDinarides 2000 Conference, Dubrovnik: Dubrovnik, PANCARDI, p. 140.

Pamić, J., McKee, H.E., Bullen, D.T., and Lanphere, A.M., 1995, Tertiary volcanic rocks from the southern Pannonian Basin, Croatia: International Geology Review, v. 37, p. 259-283.

Pamić, J., Gusic, I., and Jelaska, V., 1998, Geodynamic evolution of the central Dinarides: Tectonophysics, v. 297, no. 1-4, p. 251-268, doi: 10.1016/ S0040-1951(98)00171-1.

Pamić, J., Balen, D., and Herak, M., 2002a, Origin and geodynamic evolution of late Paleogene magmatic associations along the Periadriatic-SavaVardar magmatic belt: Geodinamica Acta, v. 15, no. 4, p. 209-231, doi: 10.1016/S0985-3111(02)01089-6.

Pamić, J., Tomljenovic, B., and Balen, D., 2002b, Geodynamic and petrogenetic evolution of Alpine ophiolites from the central and NW Dinarides: An overview: Lithos, v. 65, no. 1-2, p. 113-142, doi: 10.1016/S00244937(02)00162-7.

Pécskay, Z., Lexa, J., Szakács, A., Balogh, K., Seghedi, I., Konečný, V., Kovács, M., Márton, E., Kaličak, M., Széky-Fux, V., Póka, T., Gyarmati, P., Edelstein, O., Rosu, E., and Žec, B., 1995, Space and time distribution of Neogene-Quaternary volcanism in the Carpatho-Pannonian region: Acta Vulcanologica, v. 7, no. 2, p. 15-28.

Prelević, D., Foley, S.F., Romer, R.L., Cvetković, V., and Downes, H., 2005, Tertiary ultrapotassic volcanism in Serbia: Constraints on petrogenesis and mantle source characteristics: Journal of Petrology, v. 46, no. 7, p. 1443-1487, doi: 10.1093/petrology/egi022. 
Rapp, R.P., Shimizu, N., Norman, M.D., and Applegate, G.S., 1999, Reaction between slab-derived melts and peridotite in the mantle wedge: Experimental constraints at $3.8 \mathrm{GPa}$ : Chemical Geology, v. 160, no. 4, p. 335356, doi: 10.1016/S0009-2541(99)00106-0.

Rosenbaum, J.M., Wilson, M., and Downes, H., 1997, Multiple enrichment of the Carpathian-Pannonian mantle: $\mathrm{Pb}-\mathrm{Sr}-\mathrm{Nd}$ isotope and trace element constraints: Journal of Geophysical Research, Solid Earth, v. 102, no. B7, p. 14,947-14,961, doi: 10.1029/97JB01037.

Santos, J.F., Scharer, U., Ibarguchi, J.I.G., and Girardeau, J., 2002, Genesis of pyroxenite-rich peridotite at Cabo Ortegal (NW Spain): Geochemical and $\mathrm{Pb}-\mathrm{Sr}-\mathrm{Nd}$ isotope data: Journal of Petrology, v. 43, no. 1, p. 17-43, doi: 10.1093/petrology/43.1.17.

Schmid, S.M., Fuegenschuh, B., Kissling, B., and Schuster, R., 2004, Transect IV, in Cavazza, W., Roure, F., Spakman, W., Stampfli, G.M., and Ziegler, P.A., eds., TRANSMED Atlas-The Mediterranean Region from Crust to Mantle: Berlin, Heidelberg, Springer (CD-ROM).

Seghedi, I., Downes, H., Szakacs, A., Mason, P.R.D., Thirlwall, M.F., Rosu, E., Pecskay, Z., Marton, E., and Panaiotu, C., 2004, NeogeneQuaternary magmatism and geodynamics in the Carpathian-Pannonian region: A synthesis: Lithos, v. 72, no. 3-4, p. 117-146, doi: 10.1016/ j.lithos.2003.08.006.

Spakman, W., 1990, Tomographic images of the upper mantle below centralEurope and the Mediterranean: Terra Nova, v. 2, no. 6, p. 542-553.

Szabó, C., and Szabó-Balog, A., 1986, Mineralogy and petrography of pyroclastics in Eocene/Oligocene boundary profiles (Hungary): Annals Universitas Scientarum Sectio Geologica, v. 26, p. 33-41.

Szabó, C., Harangi, S., and Csontos, L., 1992, Review of Neogene and Quaternary volcanism of the Carpathian Pannonian region: Tectonophysics, v. 208, no. 1-3, p. 243-256, doi: 10.1016/0040-1951(92)90347-9.

Szabó, C., Kubovics, I., and Molnar, Z., 1993, Alkaline lamprophyre and related dyke rocks in NE Transdanubia, Hungary-Rhe Alcsutdoboz-2 (Ad-2) borehole: Mineralogy and Petrology, v. 47, no. 2-4, p. 127-148, doi: $10.1007 /$ BF01161563.

Szabó, C., Falus, G., Zajacz, Z., Kovács, I., and Bali, E., 2004, Composition and evolution of lithosphere beneath the Carpathian-Pannonian region:
A review: Tectonophysics, v. 393, no. 1-4, p. 119-137, doi: 10.1016/ j.tecto.2004.07.031.

Szepesházy, K., 1973, Upper Cretaceous and Paleogene Formations of the Northwest Tiszántúl: Budapest, Akadémiai Kiadó, 215 p.

Tari, G., 1994, Alpine Tectonics of the Pannonian Basin [Ph.D. thesis]: Houston, Rice University, $501 \mathrm{p}$.

Tari, G., Báldi, T., and Báldi-Beke, M., 1993, Paleogene retroarc flexural basin beneath the Neogene Pannonian Basin-A geodynamic model: Tectonophysics, v. 226, no. 1-4, p. 433-455, doi: 10.1016/0040-1951(93)90131-3.

Tari, G., Dövényi, P., Dunkl, I., Horváth, F., Lenkey, L., Stefanescu, M., Szafián, P., and Tóth, T., 1999, Lithospheric structure of the Pannonian Basin derived from seismic, gravity and geothermal data, in Durand, B., Jolivet, L., Horváth, F., and Seranne, M., eds., The Mediterranean Basins: Tertiary Extension within the Alpine Orogen: Geological Society of London Special Publication 156, p. 215-250.

Tomljenovic, B., and Csontos, L., 2001, Neogene-Quaternary structures in the border zone between Alps, Dinarides and Pannonian Basin (Hrvatsko Zagorje and Karlovac Basins, Croatia): International Journal of Earth Sciences, v. 90, no. 3, p. 560-578, doi: 10.1007/s005310000176.

von Blanckenburg, F., Früh-Green, G., Diethelm, K., and Stille, P., 1992, NdSr-, O-isotopic and chemical evidence for a two-stage contamination history of mantle magma in the central-Alpine Bergell intrusion: Contributions to Mineralogy and Petrology, v. 110, p. 33-45, doi: 10.1007/ BF00310880.

von Blanckenburg, F., Kagami, H., Deutsch, A., Oberli, F., Meier, M., Wiedenbeck, M., Barth, S., and Fischer, H., 1998, The origin of Alpine plutons along the Periadriatic lineament: Schweizerische Mineralogische und Petrographische Mitteilungen, v. 78, no. 1, p. 55-66.

Wein, G., 1969, Tectonic review of the Neogene covered areas of Hungary: Acta Geologica Hungarica, v. 13, p. 399-436.

Wortel, M.J.R., and Spakman, W., 2000, Geophysics-Subduction and slab detachment in the Mediterranean-Carpathian region: Science, v. 290 no. 5498, p. 1910-1917, doi: 10.1126/science.290.5498.1910.

Manuscript Accepted by the Society 9 June 2006 